\title{
EQUITY OPTIONS, CREDIT DEFAULT SWAPS AND LEVERAGE: A SIMPLE STOCHASTIC-VOLATILITY MODEL FOR EQUITY AND CREDIT DERIVATIVES
}

\author{
Gaia Barone ${ }^{(*)}$ \\ (LUISS Guido Carli University of Rome) \\ gbarone@luiss.it \\ Original version: February 2011 Current version: November 2013
}

\begin{abstract}
The aim of this paper is to define a model which allows traders to assess the value of equity and credit derivatives in a unified framework. We propose closed-form formulas which traders could use to evaluate equity, equity options and credit default swaps (CDSs) in a consistent way. The model can also be used to solve the inverse problem, that is to extract credit-risk sensitive information from market quotes of equity/credit derivatives. In particular, we wish to estimate the firm's leverage, as it is perceived by traders. This goal is achieved within a model $a$ la Leland (1994), where stockholders have a perpetual American option to default. After making the case for modeling debt in terms of a single perpetual-bond equivalent issue, we define leverage, show the stochastic nature of equity volatility and derive the term structures of default probabilities and credit spreads by making use of the first-passage time distribution function. Then, we give new formulas for call and put options written on stockholders' equity. The formulas, which depend on the leverage parameter $L$ and make use of the univariate normal distribution function, are consistent with the volatility skew observed in the equity options market and converge to the Black-Scholes-Merton (BSM) equations for $L \rightarrow 1$. All the Greeks are simple functions of the standard corresponding letters of the BSM model. The paper concludes with an application of the model to the case of Lehman Brothers and General Motors.
\end{abstract}

Journal of Economic Literature classification: G13 (Financial Economics, General Financial Markets, Contingent Pricing; Options Pricing).

Keywords: equity options, credit default swaps, leverage, stochastic volatility, perpetual options, first-touch digitals, Greeks, default probabilities, put-call parity.

(*) This paper has been written as part of the requirements for Tor Vergata doctorate in Money and Finance. I wish to thank Domenico Cuoco (my thesis supervisor), Jeffrey Williams and Roberto Renò for their helpful comments on previous drafts. The usual disclaimer applies. 


\section{CONTENTS}

1. Introduction...3

2. Capital Structure...4

Stakeholders...5

Dynamics of Assets' Value...5

Contracts...6

Payouts...7

Default Point and Renegotiation...7

Greeks...8

Leverage...8

Equity Volatility...8

The Case for Debt with Infinite-Maturity...9

Differences with Respect to Leland's Original Model...11

3. Term Structure of Default Probabilities and Credit Default Swaps...12

Default Probabilities...12

CDS Spreads...14

4. Equity Options...15

Put-Call Parity...16

Implementing the Model...17

5. Two Applications: Lehman Brothers and General Motors...18

Lehman Brothers...19

General Motors...21

6. Conclusions...22

References...24 


\section{INTRODUCTION}

The aim of this paper is to define a model which allows traders to assess the value of equity and equity/credit derivatives in a unified framework. We propose closed-form formulas which traders could use to evaluate equity, equity options and credit default swaps (CDSs) in a consistent manner. The model can also be used to solve the inverse problem, that is to extract credit-risk sensitive information from market quotes. In particular, the model allows an estimate of the firm's leverage, as it is perceived by traders.

In equity option markets, traders often quote the implied volatilities of European options - calculated according to the Black-Scholes-Merton model - rather than prices. The quotes reflect the shape of the probability distribution of future returns of the underlying asset. The implied volatilities generally decrease as the strike price increases, showing a typical downward-sloping volatility skew. This is consistent with the hypothesis that the actual distribution of future returns used by option traders has extra weight on the left tail with respect to the normal distribution of Black-ScholesMerton model.

One possible explanation for the volatility skew in equity options concerns leverage: ${ }^{1}$

As a company's equity declines in value, the company's leverage increases. This means that the equity becomes more risky and its volatility increases. As a company's equity increases in value, leverage decreases. The equity then becomes less risky and its volatility decreases. This argument suggest that we can expect the volatility of a stock to be a decreasing function of the stock price ...

To define leverage, we need first to define debt. A useful approach is to assume that the mixture of bonds with different coupons, bank loans and leases of a firm can be approximated by a single issue of a perpetual fixed-rate bond with the same "stochastic duration" of the actual debt. ${ }^{2}$ The assumption of a infinitely-lived security is not only mathematically convenient, but also a good proxy for a short-term debt rolled over again and again as with perpetual floaters. This assumption has been extensively used by Leland $(1994,1995,2006,2009) .{ }^{3}$ In his model, stockholders have a perpetual American option to default. Our changes with respect to the original Leland model (1994) are in the spirit of Goldstein-Ju-Leland (2001), where equity depends on the tax rate.

In the markets for credit default swaps, the term structure of CDS spreads reflects the expectations of market participants about the firm's default risk for various time horizons (typically 1, 3, 5, 7,10 years) and the requested (credit / liquidity) premia. The main advantage of our structural model is that the default barrier is endogenously given as solution of a stockholders' maximization problem. This allows to derive closed-form formula for default probabilities and credit spreads which make use of the first-passage time distribution function. We do not need to separately estimate ad hoc values of recovery rates.

The structure of the paper is as follows. First, we characterize the different claims hold by the firm's main stakeholders, then we argue that the actual debt can be approximated by a single perpetual-bond equivalent issue and highlight the model's differences with respect to Leland original article. After defining leverage, we show the stochastic nature of equity volatility and derive the term structures of default probabilities and credit default swaps (CDSs) spreads. Then, we derive new formulas for equity options and show how the model's parameters can be estimated by using quotes of equity and equity options. In particular, we show how to use market data to extract the traders' perceptions of a firm's leverage, measured in terms of a single perpetual-bond equivalent issue.

\footnotetext{
${ }^{1}$ Hull, John C., Options, Futures, and Other Derivatives, $8^{\text {th }}$ ed., Pearson, p. 415, 2011.

${ }^{2}$ The stochastic duration of a bond is defined as the time to maturity of a zero-coupon bond with the same sensitivity to changes of interest rates, i.e. with the same basis risk. "If we wish stochastic duration, $D_{3}$, to be a proxy for basis risk of coupon bonds with the units of time, then it is natural to define it as the maturity of a discount bond with the same risk." (p. 56). See Cox, John C., INGERSOLL, Jonathan E., and Ross, Stephen A., "Duration and the Measurement of Basis Risk", Journal of Business, vol. 52, no. 1, pp. 51-61, January 1979.

${ }^{3}$ LeLAND, Hayne, "Corporate Debt Value, Bond Covenants, and Optimal Capital Structure", Journal of Finance, 49 (4), pp. 121352, September 1994. Leland, Hayne, "Bond Prices, Yield Spreads, and Optimal Capital Structure with Default Risk", Finance Working Paper no. 240, Haas School of Business, University of California at Berkeley, January 1995. Leland, Hayne, "Princeton Lectures" [Lecture 1 - Pros and Cons of Structural Models - An Introduction, Lecture 2 - A New Structural Model, Lecture 3 - Financial Synergies and the Optimal Scope of the Firm - Implications for Mergers and Structured Finance], 2006. LELAND, Hayne, "Structural Models and the Credit Crisis", China International Conference in Finance, July 8, 2009.
} 
TABLE 1 Contracts between stakeholders.

\begin{tabular}{|c|c|c|c|c|}
\hline \multirow{2}{*}{ Contracts } & \multicolumn{4}{|c|}{ Stakeholders } \\
\hline & Stockholders & Bondholders & Third parties & Tax Authority \\
\hline Firm's assets & $V_{0}$ & - & - & - \\
\hline Risk-free bond & $-Z$ & $Z$ & - & - \\
\hline Option to default & $P \equiv\left(Z-V_{b}\right) p_{b}$ & $-P \equiv-\left(Z-V_{b}\right) p_{b}$ & - & - \\
\hline Bankruptcy security & - & $-A \equiv-\alpha V_{b} p_{b}$ & $A \equiv \alpha V_{b} p_{b}$ & - \\
\hline Tax claims & $-G_{S} \equiv-\theta\left(V_{0}-Z+P\right)$ & $-G_{B}=-\theta(Z-P-A)$ & $-G_{U} \equiv-\theta A$ & $G_{0} \equiv G_{S}+G_{B}+G_{U}$ \\
\hline Total & $S_{0} \equiv(1-\theta)\left(V_{0}-Z+P\right)$ & $B_{0} \equiv(1-\theta)(Z-P-A)$ & $U_{0} \equiv(1-\theta) A$ & $G_{0} \equiv \theta V_{0}$ \\
\hline
\end{tabular}

Note: $p_{b}$ is the value of a perpetual first-touch digital option which pays $\$ 1$ when $V=V_{b}$ at default time $\tau$.

\section{CAPITAL STRUCTURE}

The contractual relationships among the various firm's "stakeholders", considered in the Leland model, can be synthesized as in Table 1. The firm's ownership is shared between stockholders, bondholders, third parties (lawyers, accountants, courts, etc.) and the tax authority, which has the right to receive the share $\theta$ of the firm's earnings ( $\theta$ is the tax rate). The assets' value, $V$, is divided in two parts: $\theta V$ to the tax authority and $(1-\theta) V$ to the other stakeholders.

Stockholders issue a perpetual bond with nominal value $Z$, coupon $C=r Z$, and market value $B$. Because of firm's limited liability, they have an option to default, that is the (perpetual) right to sell the assets at price $Z$ to the bondholders. In other terms, they have a perpetual American put option, with strike $Z$ and market value $P$, written on $V$.

When $V=V_{b}$, stockholders exercise their option to default. This prevents equity's value to become negative. When the (put) option is exercised, stockholders sell the firm's assets, whose value is $V_{b}$, and receive $Z$ from bondholders. Such a bankruptcy triggers the execution of another contract. When the firm defaults, third parties claim a share $\alpha$ of the firm.

Therefore, the contracts "negotiated" among the various parties are as follows:

1. stockholders use their own capital to buy the firm's assets. Assets, whose current value is $V_{0}$, can be tangible and intangible (including human capital);

2. Tax Authority claims a share $\theta$ of the firm's assets as soon as the firm is created (the Tax Authority is a "special partner" of stockholders);

3. bondholders buy a perpetual fixed-rate bond from stockholders. The face value of the corporate bond, with coupon $C$, is $Z$. The bond contains two embedded options: a short perpetual option to default in favor of stockholders, and a short perpetual digital option (or bankruptcy security) in favor of third parties. The option to default, with strike $Z$, is optimally exercised at the default time $\tau$, when $V=V_{b}$. The perpetual digital option, with barrier $V_{b}$, offers a rebate $\alpha$ $V_{b}(0<\alpha<1)$ at $\tau$. As soon as the bond is issued, the tax burden $\theta V_{0}$ is redistributed among the three firm's claimants, to include the newcomers (bondholders and third parties).

The current values of the four securities (stock, corporate bond, bankruptcy security, tax claim) are, respectively, $S_{0}, B_{0}, U_{0}, G_{0}$.

Here we assume that individuals (stockholders, bondholders, third parties) are taxed at the same effective rate, $\theta$. Besides, we assume that stockholders, bondholders, third parties are taxed, respectively, only when dividends, interests and fees are paid. This means, in particular, that - in order to avoid double taxation - retained earnings are not taxed. ${ }^{4}$

\footnotetext{
${ }^{4}$ In the notation used by Goldstein-Ju-Leland (2001), interest payments to investors are taxed at a personal rate $\tau_{i}$, "effective" dividends are taxed at $\tau_{d}$, and corporate profits are taxed at $\tau_{c}$. We assume that $\tau_{d}=\tau_{i}$ and $\tau_{c}=0$. Therefore, the effective tax rate, $\tau_{\text {eff, }}$ defined by $\left(1-\tau_{\mathrm{eff}}\right)=\left(1-\tau_{c}\right)\left(1-\tau_{d}\right)$ is simply equal to $\tau_{d}=\tau_{i}$ (and to $\theta$, in our notation).
} 


\section{Stakeholders}

The Tax Authority is long on a simple linear contract, with current value

$$
G_{0} \equiv \theta V_{0}
$$

This is the result of three claims:

1. a claim toward stockholders, with current value $G_{S}=\theta\left(V_{0}-Z+P\right)$;

2. a claim toward bondholders, with current value $G_{B}=\theta(Z-P-A)$;

3. a claim toward third parties, with current value $G_{U}=\theta A$.

Third parties (lawyers, etc.) have a portfolio with current value

$$
U_{0} \equiv(1-\theta) A
$$

They are:

1. long on a perpetual bankruptcy security, with current value $A$, bought from bondholders;

2. short on the tax claim $G_{U} \equiv \theta A$.

Bondholders have a portfolio with current value

$$
B_{0} \equiv(1-\theta)(Z-P-A)
$$

They are:

1. long on a perpetual risk-free bond, with constant value $Z$, bought from stockholders;

2. short on a perpetual option to default, with current value $P$, sold to stockholders;

3. short on a perpetual bankruptcy security, with current value $A$, sold to third parties;

4. short on the tax claim $G_{B}=\theta(Z-P-A)$.

Finally, stockholders have a portfolio with current value

$$
S_{0} \equiv(1-\theta)\left(V_{0}-Z+P\right)
$$

They are:

1. long on the firm's assets, with current value $V_{0}$;

2. short on a perpetual risk-free bond, with constant value $Z$, sold to bondholders;

3. long on a perpetual option to default, with current value $P$, bought from bondholders;

4. short on the tax claim $G_{S}=\theta\left(V_{0}-Z+P\right)$.

Note that the total value of liabilities, $S_{0}+B_{0}+U_{0}+G_{0}$, should be equal to the value of the firm's assets, $V_{0}$ :

$$
\begin{aligned}
S_{0}+B_{0}+U_{0}+G_{0} & =(1-\theta)\left(V_{0}-Z+P\right)+(1-\theta)(Z-P-A)+(1-\theta) A+\theta V_{0} \\
& =V_{0}
\end{aligned}
$$

\section{Dynamics of Assets' Value}

The dynamics for the value, $V$, of the firm's assets is described by a diffusion-type stochastic process with stochastic differential equation

$$
d V=\left(\mu_{V}-q_{V}\right) V d t+\sigma_{V} V d z
$$

where

$\mu_{V}$ is the instantaneous expected rate of return on the firm per unit time;

$q_{V}$ is the payout rate (to shareholders, bondholders and Tax Authority);

$\sigma_{V}$ is the asset volatility (i.e. the standard deviation of the assets' rate of return per unit of time);

$d z$ is a standard Wiener process 
Because of Merton's hedging argument, the price, $f$, of any time-insensitive derivative with no intermediate payments (as the perpetual option to default or the bankruptcy security) should satisfy the following differential equation

$$
\frac{1}{2} \frac{d^{2} f}{d V^{2}} \sigma_{V}^{2} V^{2}+\left(r-q_{V}\right) V \frac{d f}{d V}-r f=0
$$

where $r$ is the risk-free interest rate.

In this context, it is appropriate to note that Merton's hedging argument does hold even if all of the firm's assets are not tradable nor observable. Although $V$ may not be the value of a traded asset, trading of equity (or other contingent claims) allows use of $V$ as the state variable: ${ }^{5}$

To understand the intuition of the replication argument, consider an analogy with an ordinary stock option model. Fundamentally, the option can be priced precisely because we can replicate its payoff using the stock and risk free bonds. However, we can just as well value the stock by replicating its payoff using the (traded) option. In the same fashion, we can value the firm's assets using stocks and risk free bonds. [Ericsson \& Reneby (2002), p. 5]

Under the assumption of a geometric Brownian motion for $V$, we can price the contracts negotiated by the various stakeholders.

\section{Contracts}

The current value, $A$, of the bankruptcy security is equal to:

$$
A=\alpha V_{b} p_{b}
$$

where

$\alpha$ is the ratio between (direct and indirect) bankruptcy costs and the market value of assets prior to bankruptcy; ${ }^{6}$

$V_{b}$ is the optimal default trigger, chosen by stockholders to maximize the value of equity: ${ }^{7}$

$$
V_{b}=Z \frac{\gamma_{2}}{\gamma_{2}-1}
$$

$p_{b}$ is the value of a perpetual first-touch digital option which pays $\$ 1$ when $V=V_{b}:^{8}$

$$
p_{b}=\left(V_{0} / V_{b}\right)^{\gamma_{2}}
$$

$\gamma_{2}$ is the elasticity of the perpetual first-touch digital option with respect to $V$ :

$$
\gamma_{2} \equiv \frac{-\left(r-q_{V}-\sigma_{V}^{2} / 2\right)-\sqrt{\left(r-q_{V}-\sigma_{V}^{2} / 2\right)^{2}+2 \sigma_{V}^{2} r}}{\sigma_{V}^{2}}
$$

$Z$ is the constant value of a perpetual risk-free bond:

$$
Z=\frac{C}{r}
$$

$C$ is the instantaneous coupon per year of a perpetual risk-free bond.

\footnotetext{
${ }^{5}$ ERICSSON, Jan, and Reneby, Joel, “A Note on Contingent Claims Pricing with Non-Traded Assets”, SSE/EFI Working Paper Series in Economics and Finance No. 314, June 2002.

${ }^{6}$ Goldstein-Ju-Leland (2001, footnote 20, p. 497) report that direct bankruptcy costs, estimated by Warner (1977), are about $1 \%$ of assets' value: "As measured here, the cost of bankruptcy is on average about one percent of the market value of the firm prior to bankruptcy" [Warner (1977), p. 377]. See WARNER, Jerold B., "Bankruptcy Costs: Some Evidence", Journal of Finance, vol. 32, no. 2, pp. 337-47, May 1977. However, taking account for indirect costs, Goldstein-Ju-Leland choose $\alpha=5 \%$ in their base case.

${ }^{7}$ As we will see later, this is different from the default trigger originally derived by Leland [1994, Equation (14), p. 1222].

${ }^{8}$ For a proof of $p_{b}$ see, for instance, BARONE, Gaia, "European Compound Options Written on Perpetual American Options", Journal of Derivatives, Spring 2013.
} 
The current value, $P$, of the option to default is equal to: ${ }^{9}$

$$
P=\left(Z-V_{b}\right) p_{b}
$$

Therefore, substituting (10) into (4) gives the current value, $S_{0}$, of equity as

$$
S_{0} \equiv(1-\theta)\left[V_{0}-Z+\left(Z-V_{b}\right)\left(V_{0} / V_{b}\right)^{\gamma_{2}}\right]
$$

\section{Payouts}

The model does not allow the firm to change its business risk, measured by $\sigma_{V}$, which is a constant, but allows for the liquidation of assets to make interest, dividend and tax payments. The firm's payout policy is defined by $q_{V}$

$$
\begin{aligned}
q_{V} V & =\text { net interests }+ \text { net dividends }+ \text { taxes } \\
& =\text { gross interests }+ \text { gross dividends } \\
& =q_{B} \frac{B}{1-\theta}+q_{S} \frac{S}{1-\theta}
\end{aligned}
$$

where

$q_{B}$ is the before-tax bond yield

$$
q_{B}=r \frac{(1-\theta) Z}{B}
$$

$q_{S}$ is the before-tax dividend yield.

The payout rate, $q_{V}$, determines the cash flow $q_{V} V$ which is taken out of the assets of the firm. What is left out of this cash flow (after paying interest on debt) is paid out to shareholders as dividends. If $q_{V} V$ is insufficient to cover coupons on the bonds, shareholders receive a negative dividend (i.e., contribute additional cash to the firm). A negative dividend (a cash-flow crisis) does not mean that that it is optimal to default: Expected future cash flows could be sufficiently high to induce stockholders to keep the firm alive.

\section{Default Point and Renegotiation}

Stockholders have to determine the optimal default point, $V_{b}$. We will suppose that $V_{b}$ is not affected by renegotiation. In other terms, stockholders of distressed firms will not try to persuade bondholders to renegotiate the contractual terms, even if they have a common interest in avoiding the losses associated with bankruptcy.

The sub-optimality of renegotiation, for both stockholders and bondholders, has been argued by Ingersoll (1987, p. 419):

A natural question at this point is, if the firm is bankrupt at time $T$, why should the bondholders not renegotiate the contract in hopes that subsequent good fortune would allow the firm to pay them in full? The answer should be clear. Under the current contract they have the right to receive all the assets of the firm. Why should they settle for less? If the firm is fortunate, they can have all of the profits rather than sharing them. Of course, they would renegotiate if the shareholders made the right concession - add more money to the firm. However, they would have to add enough to make up the bankruptcy shortfall plus an amount equal to whatever claim on the refinanced firm they would like to own. But again, why should they do that? It would cost more than the value they would receive in return.

Therefore we will assume that, if bankruptcy occurs, bondholders receive all assets (after costs) and stockholders none.

\footnotetext{
${ }^{9}$ Note that our $Z-P$ is equal to $F(V)$ in Black \& Cox [(1976), Equation (16), p. 364], where $c=r Z, \bar{V}=V_{b}, V=V_{0}$ and $\alpha=-\gamma_{2}$ :

$$
F(V)=\frac{c}{r}+\left(\bar{V}^{\alpha+1}-\frac{c}{r} \bar{V}^{\alpha}\right) V^{-\alpha}
$$
}


The optimal default point, $V_{b}$, is chosen by stockholders as the level of $V$ that maximizes the value of equity. By (11), maximizing $S_{0}$ with respect to $V_{b}$ gives

$$
V_{b}=Z \frac{\gamma_{2}}{\gamma_{2}-1}
$$

\section{Greeks}

By (4), the value of equity is

$$
S_{0} \equiv(1-\theta)\left(V_{0}-Z+P\right)
$$

and, by (10) and (8), the value of the perpetual option to default is

$$
P=\left(Z-V_{b}\right)\left(V_{0} / V_{b}\right)^{\gamma_{2}}
$$

Therefore, the delta, $\Delta_{P}$, and gamma, $\Gamma_{P}$, of the perpetual option to default are

$$
\begin{gathered}
\Delta_{P} \equiv \frac{\partial P}{\partial V}=\gamma_{2} \frac{P}{V} \\
\Gamma_{P} \equiv \frac{d^{2} P}{d V^{2}}=\frac{\gamma_{2}\left(\gamma_{2}-1\right) P}{V^{2}}
\end{gathered}
$$

and the delta, $\Delta_{S}$, and gamma, $\Gamma_{S}$, of equity are

$$
\begin{gathered}
\Delta_{S} \equiv \frac{d S}{d V}=(1-\theta)\left(1+\Delta_{P}\right) \\
\Gamma_{S} \equiv \frac{d^{2} S}{d V^{2}}=(1-\theta) \Gamma_{P}
\end{gathered}
$$

By taking the limits of $\Delta_{S}$ for $V \rightarrow V_{b}$ and $V \rightarrow \infty$, we can see that $0 \leq \Delta_{S}<(1-\theta)$. Besides, $\Gamma_{S}>0$.

Therefore, $S$ is a convex function of $V$, consistently with the "option-like" nature of equity. Figure 1 reports equity, $S$, as a function of asset's value, $V$, for different levels of debt's notional value, $Z$

\section{Leverage}

We define leverage, $L$, as the ratio between the non-Government value, $(1-\theta) V$, of firm's assets and the value, $S$, of equity:

$$
L=\frac{(1-\theta) V}{S}
$$

Substituting (15) into (18) and taking the limits of $L$ for $V \rightarrow \infty$ and $V \rightarrow V_{b}$ shows that $1<L<+\infty$.

\section{Equity Volatility}

By Itô's lemma, the equity volatility, $\sigma_{S}$, is

$$
\sigma_{S}=\frac{\Delta_{S} V \sigma_{V}}{S}
$$

Substituting (16)-(18) into (19) gives

$$
\sigma_{S}=\left(1+\gamma_{2} \frac{P}{V}\right) L \sigma_{V}
$$




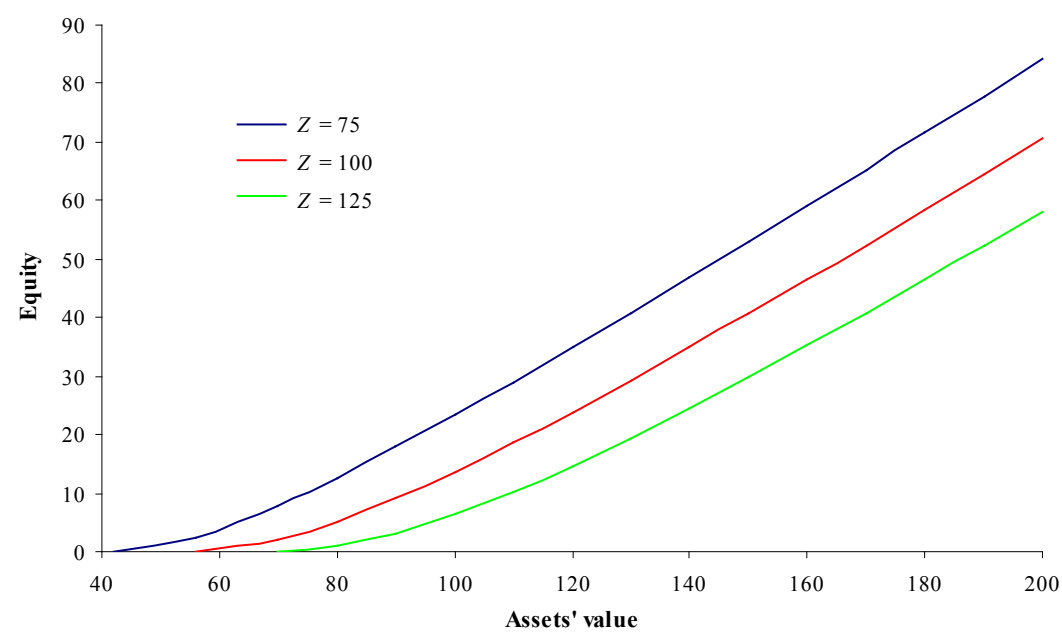

Figure 1 Equity, $S$, as a function of asset's value, $V$, for different levels of debt's notional value, $Z$. $\left(r=4 \%, q_{V}=6 \%, \sigma_{V}=10 \%, \theta=35 \%, \alpha=5 \%\right)$.

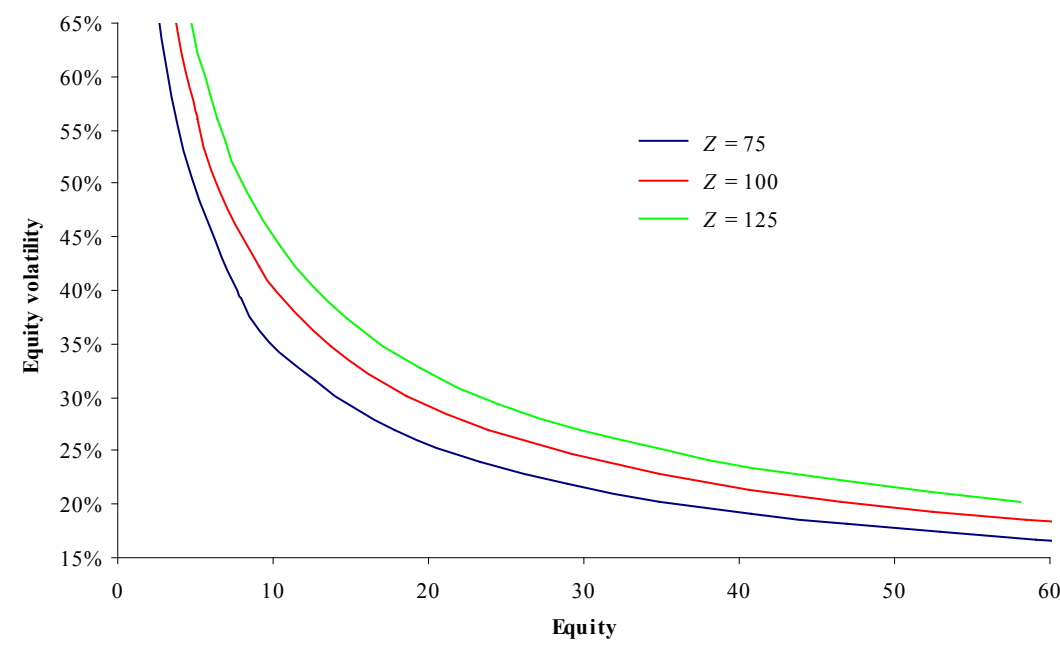

Figure 2 Equity volatility, $\sigma_{S}$, as a function of equity's value, $S$, for different levels of debt's notional value, $Z$. $\left(r=4 \%, q_{V}=6 \%, \sigma_{V}=10 \%, \theta=35 \%, \alpha=5 \%\right)$.

Equation (20) reveals the stochastic nature of equity volatility, which is a complex function of $V{ }^{10}$ Taking the limits of $\sigma_{S}$ for $V \rightarrow \infty$ and $V \rightarrow V_{b}$ shows that $\sigma_{V}<\sigma_{S}<+\infty$.

Figure 2 reports equity volatility, $\sigma_{S}$, as a function of equity's value, $S$, for different levels of debt's nominal value, $Z$.

Some values of $\sigma_{S}$, as a function of $Z, q_{V}$ and $\sigma_{V}$, are shown in Table 2, together with dividend yield $\left(q_{S}\right)$, leverage $(L)$, default trigger $\left(V_{b}\right)$, and values of the firm's stakes $\left(S_{0}, B_{0}, U_{0}, G_{0}\right)$.

\section{The Case for Debt with Infinite-Maturity}

A fundamental property of the Leland model is that debt is approximated by a single perpetual bond. While equity is simply a perpetual, residual claim on firm's assets, debt is much more difficult to define in general terms. It can be devised in various ways.

\footnotetext{
${ }^{10}$ Equation (20) shows that $\sigma_{S}$ is a function of the random asset value, $V$. Strictly speaking, our model is a local-volatility model, which belongs to the more general class of stochastic-volatility models. The term fully stochastic-volatility has been often used to describe models where the asset volatility has a randomness of its own and is driven by a different Wiener process.
} 
TABLE 2 The firm's stakes $\left(S_{0}, B_{0}, U_{0}, G_{0}\right)$, default trigger $\left(V_{b}\right)$, leverage $(L)$, dividend yield $\left(q_{S}\right)$ and equity volatility $\left(\sigma_{S}\right)$.

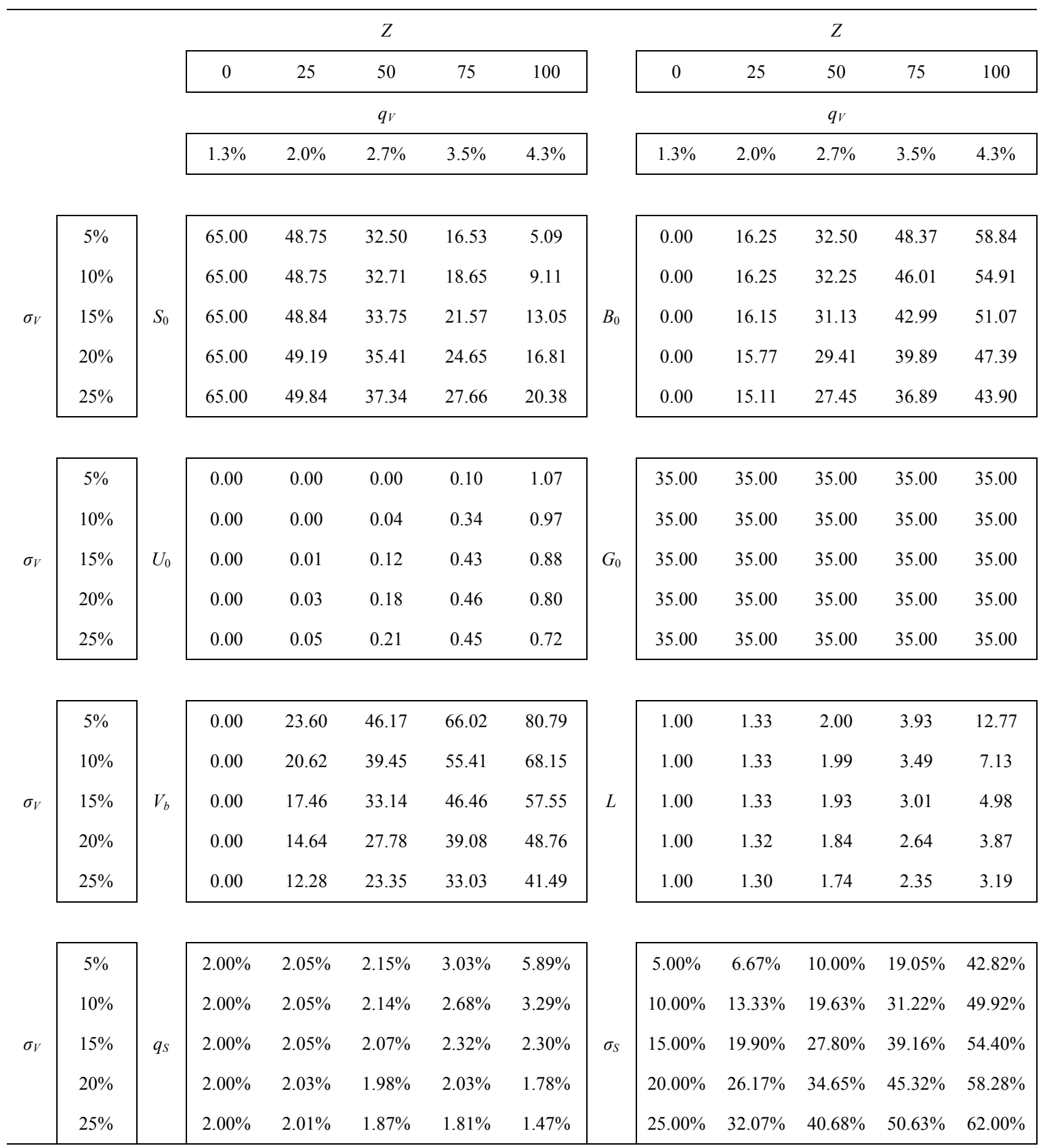

Note: $V_{0}=100, r=4 \%, \theta=35 \%, \alpha=5 \%$.

Often debt has a finite maturity, but this is not always the case. Leland (1994) assumes that it has an infinite maturity:

Very long time horizons for fixed obligations are not new, either in theory or in practice. The original Modigliani and Miller (1958) argument assumes debt with infinite maturity. Merton (1974) and Black and Cox (1976) look at infinite maturity debt in an explicitly dynamic model. Since 1752 the Bank of England has, on occasion, issued Consols, bonds promising a fixed coupon with no final maturity date.

And preferred stock typically pays a fixed dividend without time limit. [Leland (1994, p. 1215)]

Debt can be coupon-bearing or have no coupon, can be repaid by amortization or by a balloon payment at maturity, can pay a fixed, variable or step (mixed) interest, can be assisted by option-like covenants (in favor of the issuer or the holder), can include not-paid salaries and delayed payments 
to suppliers, can have different priority and subordination in the event of dissolution of the firm. Last, but not least, debt is always embedded in derivatives contracts which the firm could have entered into. The debt embedded in derivatives contracts can be extremely relevant: ${ }^{11}$

Long-Term Capital Management used its $\$ 2.2$ billion in capital from investors as collateral to buy $\$ 125$ billion in securities, and then used those securities as collateral to enter into exotic financial transactions valued at $\$ 1.25$ trillion. [Kahn and Truell (1998)]

In the well-known Moody's KMV approach, the reference debt - used to define the "default point" is simply equal to the short-term liabilities plus half of long-term liabilities, both measured in nominal, accounting, book units. ${ }^{12}$

Over time, the firm's financial structure (leverage, maturity, etc.) changes. Debt can be rolledover into other longer-maturity loans. In particular, firms can use revolving credit lines or loan commitments - made by a bank or other financial institution - to increase the flexibility of their financial structure.

Theoretically, firms can roll-over their debt an infinite number of times. This makes reasonable to approximate the actual debt structure with a unique perpetual fixed-rate bond, as in Merton (1974), Black-Cox (1976), Leland (1994), Goldstein-Ju-Leland (2001) and many other papers. ${ }^{13}$

From a theoretical standpoint, the time independency of perpetual securities assures that the firm's capital structure does not change abruptly over time, thus simplifying the analysis. ${ }^{14}$

From an empirical standpoint, the assumption of a single perpetual issue is an important advantage with respect to models which assume a finite-maturity debt, because there is no need to estimate the debt's maturity parameter, $T .^{15}$

\section{Differences with Respect to Leland's Original Model}

The firm's capital structure we defined is different from that used by Leland (1994) in his original article. As in Leland, the value of equity, $S$, does not depend on the parameter $\alpha$, which measures bankruptcy costs. However, differently from Leland, equity does depend on the effective tax rate, $\theta$.

The definitions of debt, $D$, and equity, $E$, used by Leland [1994, Equations (7) and (13)] can be obtained, respectively, by merging the claims of bondholders with the claims of the Tax Authority towards bondholders and by merging the claims of stockholders with the claim of the Tax Authority towards stockholders plus "the value of the tax deduction of coupon payments", $T B(V)=\theta Z\left(1-p_{b}\right)$.

\footnotetext{
${ }^{11}$ Kahn, Joseph, and Truell, Peter, “Troubled Investment Fund's Bets Now Estimated at \$1.25 Trillion”, Wall Street Journal, September 26, 1998 .

${ }^{12}$ Moody's KMV defines the default point as "The point to which a firm's asset value must fall before the firm is unable to raise capital to meet either a principal or interest payment. It is approximately equal to the total amount of short-term liabilities, plus half of the long-term liabilities (precise definition varies by industry)." See Moody's KMV "Credit Monitor Quick Reference", 2004.

${ }^{13}$ BLACK, Fischer S., and CoX, John C., "Valuing Corporate Securities - Some Effects of Bond Indenture Provisions", Journal of Finance 31 (2), 351-367, 1976. GoldsteIn, Robert, JU, Nengjiu, and LELAND, Hayne, "An EBIT-Based Model of Dynamic Capital Structure", Journal of Business, vol. 74, no. 4, 2001.

Leland (1995) has also proposed an "exponential model" where the firm retires the perpetual debt at a proportional rate $m$ through time. This roll-over debt structure, with regular repayments and renewals of principal and of coupon, should guarantee a stationary debt structure. However Décamps and Villeneuve (2008) show that this extension of Leland's original model does not allow close-form formulas because the default point is not constant anymore, but depends on time. See LELAND, Hayne, "Bond Prices, Yield Spreads, and Optimal Capital Structure with Default Risk", Finance Working Paper no. 240, Haas School of Business, University of California at Berkeley, January 1995; DÉCAMPS, Jean-Paul, and VILLENEUVE, Stéphane, "On the modeling of Debt Maturity and Endogenous Default - A Caveat", Working Paper, May 2008.

${ }^{14}$ Note that, because the debt is fixed in nominal terms, the actual leverage tends to decrease in real terms over time. An alternative assumption would be to model debt as a perpetual floating-rate bond. However, if coupons were continuously paid at the rate $r$, the basis risk, i.e. the bond's sensitivity to interest rates, would be null (and this would contradict the empirical evidence). See Cox, John C., INGERSOLL, Jonathan E., and Ross, Stephen A., "An Analysis of Variable Rate Loan Contracts", Journal of Finance, vol. 35, no. 2, pp. 389-403, May 1980.

${ }^{15}$ Merton, Robert C., "On the Pricing of Corporate Debt: The Risk Structure of Interest Rates,” Journal of Finance 29, No. 2 (May 1974), pp. 449-470, reprinted in Robert C. Merton, Continuous-Time Finance, Chapter 12 (Malden, MA: Blackwell, 1990), pp. $388-412$.

There is some evidence that the longer is $T$ the better is the Merton model fit: "Experimenting with different choices, we find that choosing a longer maturity, and hence giving a larger weight to volatility, generates predictions more correlated with market observations. We present our results based on $T=10$ ". See BAI, Jennie, and WU, Liuren, “Anchoring Corporate Credit Spreads to Firm Fundamentals", Working Paper, June 2010 (p. 9).
} 
By Table 1 and Equations (8) and (10):

$$
\begin{aligned}
D & \equiv B_{0}+G_{B} \\
& =(1-\theta)(Z-P-A)+\theta(Z-P-A) \\
& =Z-P-A \\
& =Z-\left(Z-V_{b}\right) p_{b}-\alpha V_{b} p_{b} \\
& =Z+\left[(1-\alpha) V_{b}-Z\right] p_{b} \\
& =Z+\left[(1-\alpha) V_{b}-Z\right]\left(V_{0} / V_{b}\right)^{\gamma_{2}}
\end{aligned}
$$

and

$$
\begin{aligned}
E & \equiv S_{0}+G_{S}+\theta Z\left(1-p_{b}\right) \\
& =(1-\theta)\left(V_{0}-Z+P\right)+\theta\left(V_{0}-Z+P\right)+\theta Z\left(1-p_{b}\right) \\
& =V_{0}-Z+P+\theta Z\left(1-p_{b}\right) \\
& =V_{0}-Z+\left(Z-V_{b}\right) p_{b}+\theta Z\left(1-p_{b}\right) \\
& =V_{0}-(1-\theta) Z+\left[(1-\theta) Z-V_{b}\right] p_{b} \\
& =V_{0}-(1-\theta) Z+\left[(1-\theta) Z-V_{b}\right]\left(V_{0} / V_{b}\right)^{\gamma_{2}}
\end{aligned}
$$

Our stricter definition of equity, $S_{0}$, is equal to the definition of equity, $E_{\text {solv }}$, used by Goldstein-JuLeland [2001, Equation (19)]. ${ }^{16}$

Some of the consequences of our different approach, with respect to Leland (1994), are:

1. the value of equity does depend on the tax rate $\theta ;{ }^{17}$

2. the default trigger, $V_{b}$, is different from (higher than) the default trigger obtained by Leland;

3. it is not possible to derive an optimal capital structure by balancing tax advantages with potential default costs.

Another consequence is that - for evaluating equity options - we cannot use the formulas derived within the original Leland model.

\section{TERM STRUCTURE OF DEFAULT PROBABILITIES AND CREDIT DEFAULT SWAPS}

\section{Default Probabilities}

Let $Q(T)$ denote the probability of default between time 0 and time $T$ (included). This is equal to the probability that $V$ reaches $V_{b}$ before $T$ (or in $T$ ). Therefore, $Q(T)$ is equal to the first-passage time distribution function: ${ }^{18}$

$$
Q(T)=N\left(-z_{1}\right)+\left(\frac{V_{0}}{V_{b}}\right)^{2(1-\lambda)} N\left(-z_{2}\right)
$$

where

$$
z_{1}=\frac{\ln \left(V_{0} / V_{b}\right)+\left(r-q_{V}-\sigma_{V}^{2} / 2\right) T}{\sigma \sqrt{T}}
$$

\footnotetext{
${ }^{16}$ According to Equation (19) of Goldstein-Ju-Leland (2001), $E_{\text {solv }}=\left(1-\tau_{\text {eff }}\right)\left(V_{\text {solv }}-V_{\text {int }}\right)$ where $V_{\text {int }}=(C / r)\left(1-p_{B}\right)$. In our notation, $S_{0}=E_{\text {solv }}, \theta=\tau_{\text {eff, }}, V_{0}-V_{b} p_{b}=V_{\text {solv }}, Z\left(1-p_{b}\right)=V_{\text {int }}, p_{b}=p_{B}$. Therefore, $S_{0}=(1-\theta)\left[V_{0}-V_{b} p_{b}-Z\left(1-p_{b}\right)\right]=(1-\theta)\left[V_{0}+\left(Z-V_{b}\right) p_{b}-Z\right]$ $=(1-\theta)\left(V_{0}+P-Z\right)$. In the notation used by Goldstein-Ju-Leland (2001), $B C_{d e f}=\alpha V_{d e f}=\alpha V_{b} p_{b}$ is the value of the bankruptcy claim. We assume that also third parties have to pay taxes. Therefore, our expression for the value, $U_{0}$, of the bankruptcy claim is equal to $\alpha V_{b} p_{b}$ pre-multiplied by $(1-\theta)$.

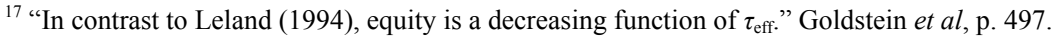

${ }^{18}$ See Equation (34b), p. 353, in Ingersoll, Jonathan E., Theory of Financial Decision Making, Rowman \& Littlefield, 1987. Transformed into our notation, $x_{0}=\ln \left(V_{0} / V_{b}\right), \mu=r-q_{V}-\sigma_{V}^{2} / 2,2 \mu / \sigma^{2}=2(\lambda-1), t_{0}=0$.
} 
TABLE 3 Default probabilities.

\begin{tabular}{lccccccccc}
\hline & \multicolumn{7}{c}{$\begin{array}{c}\text { ACTUAL DEFAULT PROBABILITIES (\%) } \\
\text { [source: Moody's (1970-2009)] }\end{array}$} \\
\cline { 2 - 10 } Rating & 1 & 2 & \multicolumn{1}{c}{ Maturity (years) } \\
\cline { 2 - 11 } Aaa & 0.000 & 0.012 & 0.012 & 0.037 & 0.105 & 0.245 & 0.497 & 0.927 & 1.102 \\
Aa & 0.022 & 0.059 & 0.091 & 0.159 & 0.234 & 0.384 & 0.542 & 1.150 & 2.465 \\
A & 0.051 & 0.165 & 0.341 & 0.520 & 0.717 & 1.179 & 2.046 & 3.572 & 5.934 \\
Baa & 0.176 & 0.494 & 0.912 & 1.404 & 1.926 & 2.996 & 4.851 & 8.751 & 12.327 \\
Ba & 1.166 & 3.186 & 5.583 & 8.123 & 10.397 & 14.318 & 19.964 & 29.703 & 37.173 \\
B & 4.546 & 10.426 & 16.188 & 21.256 & 25.895 & 34.473 & 44.377 & 56.098 & 62.478 \\
Caa & 17.723 & 29.384 & 38.682 & 46.094 & 52.286 & 59.771 & 71.376 & 77.545 & 80.211 \\
\hline
\end{tabular}

Theoretical Default Probabilities (\%)

\begin{tabular}{|c|c|c|c|c|c|c|c|c|c|c|c|}
\hline \multirow[b]{2}{*}{ Rating } & \multicolumn{9}{|c|}{ Maturity (years) } & \multirow[b]{2}{*}{$Z$} & \multirow[b]{2}{*}{$\sigma_{V}(\%)$} \\
\hline & 1 & 2 & 3 & 4 & 5 & 7 & 10 & 15 & 20 & & \\
\hline Aaa & 0.000 & 0.001 & 0.015 & 0.057 & 0.127 & 0.316 & 0.614 & 0.992 & 1.220 & 60 & 11.5 \\
\hline $\mathrm{Aa}$ & 0.000 & 0.005 & 0.051 & 0.159 & 0.314 & 0.683 & 1.208 & 1.829 & 2.196 & 65 & 12.0 \\
\hline A & 0.001 & 0.106 & 0.461 & 0.973 & 1.530 & 2.567 & 3.766 & 4.991 & 5.658 & 70 & 12.5 \\
\hline Baa & 0.210 & 2.036 & 4.528 & 6.858 & 8.860 & 11.970 & 15.092 & 18.097 & 19.768 & 80 & 15.0 \\
\hline $\mathrm{Ba}$ & 1.933 & 8.363 & 14.220 & 18.859 & 22.533 & 27.943 & 33.240 & 38.468 & 41.594 & 90 & 20.0 \\
\hline B & 4.708 & 16.491 & 26.138 & 33.488 & 39.216 & 47.592 & 55.841 & 64.196 & 69.418 & 110 & 35.0 \\
\hline $\mathrm{Caa}$ & 13.644 & 30.656 & 41.560 & 49.063 & 54.588 & 62.289 & 69.526 & 76.567 & 80.829 & 140 & 40.0 \\
\hline
\end{tabular}

Note: The theoretical default probabilities are based on Equation (21), where the risk-free interest rate $r$ has been replaced with the actual drift rate $\mu_{V}$. The model's parameters are: $V=100, \mu_{V}=5 \%, q_{V}=0 \%, \theta=35 \%, \alpha=5 \%$ (the values of $Z$ and $\sigma_{V}$ are a function of the rating class).

$$
\begin{gathered}
z_{2}=\frac{\ln \left(V_{0} / V_{b}\right)-\left(r-q_{V}-\sigma_{V}^{2} / 2\right) T}{\sigma \sqrt{T}} \\
\lambda=1+\frac{r-q_{V}-\sigma_{V}^{2} / 2}{\sigma_{V}^{2}}
\end{gathered}
$$

Equation (21) gives the term structure of unconditional (cumulative) default probabilities and allows an easy calculation of the term structure of conditional default probabilities (or hazard rates / default intensities).

Table 3 shows that, by using the actual drift rate $\mu_{V}$ instead of $r$, the model can be calibrated to fit the term structures of actual default probabilities.

In the table, historical default frequencies calculated by Moody's for different rating classes have been reported together with theoretical default probabilities obtained for different values of the model's parameters $Z$ and $\sigma_{V}$.

\footnotetext{
${ }^{19}$ It should be noted that actual default probabilities shown in the table do not include the (high) risk premiums asked by bond traders as a compensation for the (high) systematic risk of bond portfolios.
} 


\section{CDS Spreads}

Standard single-name credit default swaps (CDSs), where the protection buyer makes periodic payments and has the right to sell at par the bonds issued by the reference entity, can be priced in the framework given by the model. ${ }^{20}$

To explain the calculations, let us consider a $n$-year CDS whose payment dates are at times $t_{i}$ $(1 \leq i \leq m \times n)$, where $m$ is the number of payments per year. The value, $A_{1}$, of an annuity which pays $1 / m$ at each payment date until default, $\tau$, or maturity, $T=t_{m \times n}$, whichever comes first, is

$$
A_{1}=\frac{1}{m} \sum_{i=1}^{m \times n} e^{-y_{i} t_{i}}\left[1-Q\left(t_{i}\right)\right]
$$

where $y_{i}$ is the risk-free interest rate for maturity $t_{i}$ and $Q\left(t_{i}\right)$ is the default probability given by (21)

We assume "instant recovery". In other terms, we assume that - at default time, $\tau$ - the protection buyer receives an instant payment equal to $1-R$, where the recovery rate $R$ is endogenously given by the following formula:

$$
R=\frac{(1-\alpha) V_{b}}{Z}
$$

Substituting (14) into (23), the instant payoff $1-R$ to the protection buyer is equal to

$$
1-R=\frac{1-\alpha \gamma_{2}}{1-\gamma_{2}}
$$

The present value of the payoff is

$$
(1-R) p_{b}(T)
$$

where $p_{b}(T)$ is the value of a T-maturity first-touch digital option, which pays a unit at time $\tau(\tau \leq T)$ if the firm defaults at $\tau$.

Generally, credit default swaps specify that the protection buyer must, at default, pay the CDS spread that has accrued since the last coupon date. In order to take this accrual payment into account, we subtract one half of the regular payment from the instant payoff $1-R$ :

For reasonably small default probabilities and intercoupon periods, the expected difference in time between the credit event and the previous coupon date is just slightly less than one-half, in expectation, of the length of an intercoupon period, assuming that the default risk is not concentrated at a coupon date. Thus, for purposes of pricing in all but extreme cases, one can think of the credit swap as equivalent to payment at default of face value less recovery value less one-half of the regular default-swap premium payment [Duffie-Singleton (2003), pp. 183-4].

Therefore, the present value, $A_{2}$, of the net $\operatorname{CDS}$ payoff is

$$
A_{2}=\left[(1-R)-\frac{1}{2} \frac{s}{m}\right] p_{b}(T)
$$

where $s$ is the CDS spread per year.

The CDS contract is fair when the present value, $s A_{1}$, of the payments equals the present value, $A_{2}$, of the net payoff, or

$$
s A_{1}=A_{2}
$$

\footnotetext{
${ }^{20}$ For "Model-Based CDS Rates", see Section 8.4 in DufFie, Darrell, and Singleton, Ken J., Credit Risk, Princeton University Press, 2003.
} 
By substituting (22) and (25) into (26), the CDS breakeven spread is

$$
s=\frac{(1-R) p_{b}(T)}{\frac{1}{m}\left\{\frac{1}{2} p_{b}(T)+\sum_{i=1}^{m \times n} e^{-y_{i} t_{i}}\left[1-Q\left(t_{i}\right)\right]\right\}}
$$

where the value, $p_{b}(T)$, of a finite-maturity first-touch digital option, with barrier $V_{b}<V_{0}$, has been derived by Rubinstein and Reiner (1991) as: ${ }^{21}$

$$
p_{b}(T)=\left(V_{b} / V_{0}\right)^{a+b} N(-z)+\left(V_{b} / V_{0}\right)^{a-b} N\left(-z+2 b \sigma_{V} \sqrt{T}\right)
$$

with

$$
z \equiv \frac{\ln \left(V_{b} / V_{0}\right)}{\sigma_{V} \sqrt{T}}+b \sigma_{V} \sqrt{T} \quad a \equiv \frac{r-q_{V}-\sigma_{V}^{2} / 2}{\sigma_{V}^{2}} \quad b \equiv \frac{\sqrt{\left(r-q_{V}-\sigma_{V}^{2} / 2\right)^{2}+2 \sigma_{V}^{2} r}}{\sigma_{V}^{2}}
$$

It can be shown that (28) converges to (8) when $T \rightarrow \infty$.

\section{EQUITY OPTIONS}

Similarly to Toft (1994), Toft \& Prucyk (1996) and Barone (2011), we can derive the value, $c$, of a European call, with strike $K$ and maturity $T$, written on $S$ as: ${ }^{22}$

$$
\begin{aligned}
c & =e^{-r T} E\left(S_{T}-K \mid V_{T}>V_{T}^{*} \cap V_{t}>V_{b}\right) \times \operatorname{Prob}\left(V_{T}>V_{T}^{*} \cap V_{t}>V_{b}\right) \\
& =(1-\theta)\left(V_{d o c}+P_{u o p}-Z R_{d o c}\right)-K R_{d o c}
\end{aligned}
$$

where

$V_{d o c}$ is the value of a down-and-out asset-or-nothing call, with strike $V_{T}^{*}$ and barrier $V_{b}$, which pays $V_{T}$ at time $T$ if $V_{T}>V_{T}^{*}$ and $V_{t}>V_{b}(0<t \leq T)$ :

$$
V_{d o c}=V_{0} e^{-q_{V} T}\left[N(x)-\left(V_{b} / V_{0}\right)^{2 \lambda} N(y)\right]
$$

$P_{\text {uop }}$ is the value of an up-and-out asset-or-nothing put, with strike $P_{T}^{*}$ and barrier $P_{b}$, which pays $P_{T}$ at time $T$ if $P_{T}<P_{T}^{*}$ and $P_{t}<P_{b}$ :

$$
P_{\text {uop }}=P_{0}\left[N\left(-x_{P}\right)-\left(P_{b} / P_{0}\right)^{2 \lambda_{P}} N\left(-y_{P}\right)\right]
$$

$R_{d o c}$ is the value of a down-and-out cash-or-nothing call, with strike $V_{T}^{*}$, barrier $V_{b}$ and unit rebate $R$, which pays $R=\$ 1$ in $T$ if $V_{T}>V_{T}^{*}$ and $V_{t}>V_{b}$ :

$$
R_{d o c}=e^{-r T}\left[N\left(x-\sigma_{V} \sqrt{T}\right)-\left(V_{b} / V_{0}\right)^{2 \lambda-2} N\left(y-\sigma_{V} \sqrt{T}\right)\right]
$$

$V_{T}^{*}$ is the critical asset value that makes the call finish at the money;

$$
V_{T}^{*}=V_{0} e^{\left(r-q_{V}-\sigma_{V}^{2} / 2\right) T+\varepsilon^{*} \sigma_{V} \sqrt{T}}
$$

$P_{T}^{*}$ is the value of the perpetual first-touch digital when $V=V_{T}^{*}$;

$$
P_{T}^{*}=P_{0} e^{\left(r-\sigma_{P}^{2} / 2\right) T-\varepsilon^{*} \sigma_{P} \sqrt{T}}
$$

$\varepsilon^{*}$ is the standardized normal shock that makes the equity call finish at the money;

$N(\cdot)$ is the standard normal distribution function;

and

$$
x \equiv \frac{\ln \left(V_{0} / V_{T}^{*}\right)}{\sigma_{V} \sqrt{T}}+\lambda \sigma_{V} \sqrt{T} \quad x_{P} \equiv \frac{\ln \left(P_{0} / P_{T}^{*}\right)}{\sigma_{P} \sqrt{T}}+\lambda_{P} \sigma_{P} \sqrt{T}
$$

\footnotetext{
${ }^{21}$ Rubinstein, Mark e ReINER, Eric, "Unscrambling the Binary Code”, Risk, vol. 4, no. 9, pp. 75-83, October 1991.

${ }^{22}$ TOFT, Klaus Bjerre Toft, “Options on Leveraged Equity with Default Risk", Walter A. Haas School of Business, University of California at Berkeley, July 1994. TOFT, Klaus Bjerre Toft, and PRUCYK, Bryan, "Options on Leveraged Equity: Theory and Empirical Tests", Journal of Finance, Vol. 52, No. 3, pp. 1151-1180, July 1997. BARONE, Gaia, "Equity Options and Bond Options in the Leland Model", "Tor Vergata" University of Rome, Working Paper, March 2011. Downloadable at http://ssrn.com/author=1004723.
} 


$$
\begin{aligned}
& y \equiv \frac{\ln \left[V_{b}^{2} /\left(V_{0} V_{T}^{*}\right)\right]}{\sigma_{V} \sqrt{T}}+\lambda \sigma_{V} \sqrt{T} \quad y_{P} \equiv \frac{\ln \left[P_{b}^{2} /\left(P_{0} P_{T}^{*}\right)\right]}{\sigma_{P} \sqrt{T}}+\lambda_{P} \sigma_{P} \sqrt{T} \\
& \lambda \equiv 1+\frac{r-q_{V}-\sigma_{V}^{2} / 2}{\sigma_{V}^{2}} \quad \lambda_{P} \equiv 1+\frac{r-\sigma_{P}^{2} / 2}{\sigma_{P}^{2}} \quad \sigma_{P}=-\gamma_{2} \sigma_{V}
\end{aligned}
$$

Under the hypothesis that - if the firm defaults at $\tau$ - the buyer receives $K$ at $T$ (and not at $\tau$ ), the value, $p$, of a European put, with strike $K$ and maturity $T$, written on $S$ is

$$
\begin{aligned}
& p=e^{-r T} E\left[K-S_{T} \mid V_{T}<V_{T}^{*} \cap V_{t}>V_{b}\right] \times \operatorname{Prob}\left(V_{T}<V_{T}^{*} \cap V_{t}>V_{b}\right)+E\left[e^{-r \tau} K \mid V_{t} \leq V_{b}\right] \times \operatorname{Prob}\left(V_{t} \leq V_{b}\right) \\
& =K\left(R_{d o p}+R_{d i}\right)+(1-\theta)\left(Z R_{d o p}-V_{d o p}-P_{u o c}\right)
\end{aligned}
$$

where

$R_{d o p}$ is the value of a down-and-out cash-or-nothing put, with strike $V_{T}^{*}$, barrier $V_{b}$ and unit rebate $R$, written on $V$, which pays $R=\$ 1$ at time $T$ if $V_{T}<V_{T}^{*}$ and $V_{t}>V_{b}(0<t \leq T)$ :

$$
R_{d o p}=e^{-r T}\left\{N\left(-x+\sigma_{V} \sqrt{T}\right)-N\left(-x_{1}+\sigma_{V} \sqrt{T}\right)+\left(V_{b} / V_{0}\right)^{2 \lambda-2}\left[N\left(y-\sigma_{V} \sqrt{T}\right)-N\left(y_{1}-\sigma_{V} \sqrt{T}\right)\right]\right\}
$$

$V_{d o p}$ is the value of a down-and-out asset-or-nothing put, with strike $V_{T}^{*}$ and barrier $V_{b}$, written on $V$, which pays $V_{T}$ at time $T$ if $V_{T}<V_{T}^{*}$ and $V_{t}>V_{b}$ :

$$
V_{\text {dop }}=V_{0} e^{-q_{V} T}\left\{N(-x)-N\left(-x_{1}\right)+\left(V_{b} / V_{0}\right)^{2 \lambda}\left[N(y)-N\left(y_{1}\right)\right]\right\}
$$

$P_{\text {uос }}$ is the value of an up-and-out asset-or-nothing call, with strike $P_{T}^{*}$ and barrier $P_{b}$, written on $P$, which pays $P_{T}$ at time $T$ if $P_{T}>P_{T}^{*}$ and $P_{t}<P_{b}$ :

$$
P_{\text {uоc }}=P_{0}\left\{N\left(x_{P}\right)-N\left(x_{1 P}\right)+\left(P_{b} / P_{0}\right)^{2 \lambda_{P}}\left[N\left(-y_{P}\right)-N\left(-y_{1 P}\right)\right]\right\}
$$

$R_{d i}$ is the value of a down-and-in (at expiry) cash-or-nothing, with barrier $V_{b}$ and unit rebate $R$, written on $V$, which pays $R=\$ 1$ at time $T$ if $V_{t} \leq V_{b}(0<t \leq T)$ :

$$
R_{d i}=e^{-r T}\left[N\left(-x_{1}+\sigma_{V} \sqrt{T}\right)+\left(V_{b} / V_{0}\right)^{2 \lambda-2} N\left(y_{1}-\sigma_{V} \sqrt{T}\right)\right]
$$

and

$$
\begin{array}{ll}
x_{1} \equiv \frac{\ln \left(V_{0} / V_{b}\right)}{\sigma_{V} \sqrt{T}}+\lambda \sigma_{V} \sqrt{T} & x_{1 P} \equiv \frac{\ln \left(P_{0} / P_{b}\right)}{\sigma_{P} \sqrt{T}}+\lambda_{P} \sigma_{P} \sqrt{T} \\
y_{1} \equiv \frac{\ln \left(V_{b} / V_{0}\right)}{\sigma_{V} \sqrt{T}}+\lambda \sigma_{V} \sqrt{T} & y_{1 P} \equiv \frac{\ln \left(P_{b} / P_{0}\right)}{\sigma_{P} \sqrt{T}}+\lambda_{P} \sigma_{P} \sqrt{T}
\end{array}
$$

Table 4 shows an application of formulas (29) and (30) for call and put equity options.

\section{Put-Call Parity}

Formulas (29) and (30) satisfy the following put-call parity

$$
c-p=(1-\theta) S_{d o}-K e^{-r T}
$$

where

$S_{d o}$ is the value of a down-and-out asset-or-nothing, with barrier 0 , written on $S$, which pays $S_{T}$ at time $T$ if $S_{t}>0(0<t \leq T)$ :

$$
S_{d o}=V_{d o}+P_{u o}-Z R_{d o}
$$


TABLE 4 European equity options.

\begin{tabular}{|c|c|c|c|c|}
\hline & A & B & $\mathrm{C}$ & $\mathrm{D}$ \\
\hline 1 & Equity Options & & & \\
\hline 2 & & & & \\
\hline 3 & Asset value $\left(V_{0}\right)$ & 100 & & \\
\hline 4 & Bond face value $(Z)$ & 50 & & \\
\hline 5 & Strike price $(K)$ & 30 & & \\
\hline 6 & Time to maturity ( $T$ ) & 1 & & \\
\hline 7 & Tax rate $(\theta)$ & $35 \%$ & & \\
\hline 8 & Bankruptcy costs rate $(\alpha)$ & $5.00 \%$ & & \\
\hline 9 & Risk-free rate $(r)$ & $5.50 \%$ & & \\
\hline 10 & Payout rate $\left(q_{V}\right)$ & $3.50 \%$ & & \\
\hline 11 & Asset volatility $\left(\sigma_{V}\right)$ & $20.00 \%$ & & \\
\hline 12 & Bankruptcy trigger $\left(V_{b}\right)$ & 31.19 & & \\
\hline 13 & Option to default $(P)$ & 2.72 & & \\
\hline 14 & Option to default volatility $\left(\sigma_{P}\right)$ & $33.17 \%$ & & \\
\hline 15 & Tax claim $\left(G_{0}\right)$ & 35.00 & & \\
\hline 16 & Third parties claim $\left(U_{0}\right)$ & 0.15 & & \\
\hline 17 & Bond $\left(B_{0}\right)$ & 30.58 & & \\
\hline 18 & Equity $\left(S_{0}\right)$ & 34.27 & & \\
\hline 19 & Dividend yield $\left(q_{S}\right)$ & $2.19 \%$ & & \\
\hline 20 & Equity volatility $\left(\sigma_{S}\right)$ & $36.22 \%$ & & \\
\hline 21 & Leverage $(L)$ & 1.90 & & \\
\hline 22 & Critical asset value $\left(V_{T}{ }^{*}\right)$ & 93.09 & & \\
\hline 23 & & call & put & \\
\hline 24 & Down-and-out asset-or-nothing ( $V_{d o c}$ or $V_{d o p}$ ) & 44.67 & 18.10 & \\
\hline 25 & Up-and-out asset-or-nothing ( $P_{\text {uop }}$ or $\left.P_{\text {uoc }}\right)$ & 0.90 & 0.87 & \\
\hline 26 & Down-and-out cash-or-nothing $\left[(Z+K) R_{d o c}\right.$ or $\left.(Z+K) R_{d o p}\right]$ & 37.86 & 21.30 & \\
\hline 27 & Down-and-in cash-or-nothing ( $K R_{d i}$ ) & 0.00 & 0.00 & \\
\hline 28 & Equity option ( $c$ or $p)$ & 7.72 & 2.34 & \\
\hline 29 & & $c-p$ & $(1-\theta) S_{d o}-K e^{-r T}$ & \\
\hline 30 & Put-call parity & 5.38 & 5.38 & \\
\hline
\end{tabular}

and

$$
\begin{gathered}
V_{d o}=V_{0} e^{-q_{V} T}\left[N\left(x_{1}\right)-\left(V_{b} / V_{0}\right)^{2 \lambda} N\left(y_{1}\right)\right] \\
P_{u o}=P_{0}\left[N\left(-x_{1 P}\right)-\left(P_{b} / P_{0}\right)^{2 \lambda_{P}} N\left(-y_{1 P}\right)\right] \\
R_{d o}=e^{-r T}\left[N\left(x_{1}-\sigma_{V} \sqrt{T}\right)-\left(V_{b} / V_{0}\right)^{2 \lambda-2} N\left(y_{1}-\sigma_{V} \sqrt{T}\right)\right]
\end{gathered}
$$

and the other variables have already been defined.

Figure 3 shows the values of call and put options, as a function of the equity value, for some model's parameters. The chart also shows the put-call parity relationship, measured by the difference $c-p$.

\section{Implementing the Model}

The required inputs for estimating the value of equity options by the Black-Scholes-Merton include $S_{0}, q_{S}$ and $\sigma_{S}$. If we add leverage, $L$, to the list, we can estimate $V_{0}, q_{V}, \sigma_{V}$ and $Z$ by solving a system of four simultaneous equations. 


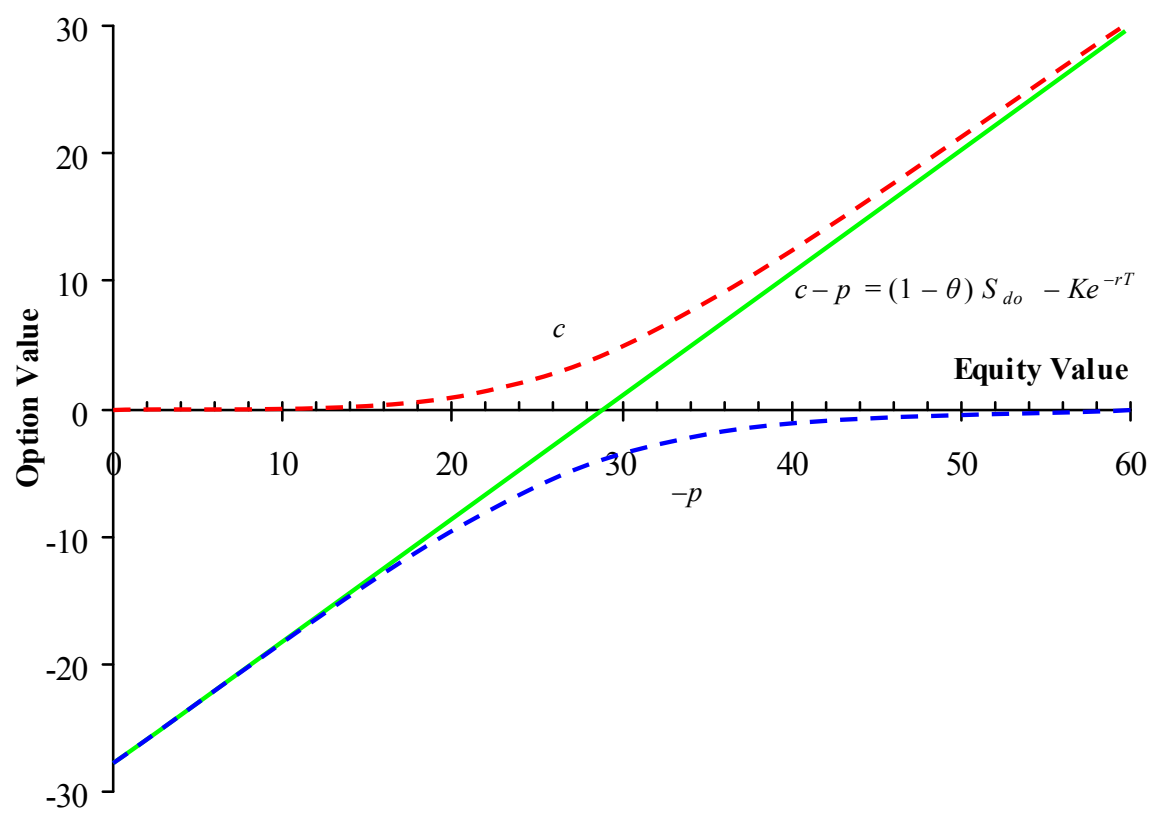

Figure 3 Equity put-call parity $\left(r=5.5 \%, q_{V}=3.5 \%, \sigma_{V}=20 \%, Z=50, \theta=35 \%, V_{b}=31.19, K=30, T=1\right)$.

The first equation sets to zero the difference between the theoretical value and the market value of equity:

$$
(1-\theta)\left[V_{0}-Z+\left(Z-V_{b}\right)\left(V_{0} / V_{b}\right)^{\gamma_{2}}\right]-S_{0}=0
$$

The second equation, derived by applying Itô's lemma, sets to zero the difference between the theoretical level and the market estimate of equity volatility:

$$
\frac{\Delta_{S} \sigma_{V} V_{0}}{S_{0}}-\sigma_{S}=0
$$

The third equation sets to zero the difference between the theoretical level and the market estimate of dividend yield:

$$
\left(q_{V} \frac{V}{S}-r \frac{Z}{S}\right)-q_{S}=0
$$

Finally, the fourth equation sets to zero the difference between the theoretical and actual level of leverage:

$$
\frac{(1-\theta) V_{0}}{S_{0}}-L=0
$$

These equations can be solved numerically. Table 5 shows a worksheet where the Excel's Solver has been used to estimate the model's parameters $V_{0}, q_{V}, \sigma_{V}, Z$ on the basis of the input list $S_{0}, q_{S}, \sigma_{S}, L$ (in addition to $r, \theta, \alpha, K$ and $T$ ).

\section{TWO APPLICATIONS: LEHMAN BROTHERS AND GENERAL MOTORS}

In Section 3, Table 3 showed the solution of an inverse problem: the calculation of implied default probabilities based on actual default probabilities reported by Moody's for some rating classes. Instead in Section 4, Table 4 and Table 5 showed the solution of a direct problem: the value of equity options based on two different input lists, which include $\left(V_{0}, q_{V}, \sigma_{V}, Z\right)$ or $\left(S_{0}, q_{S}, \sigma_{S}, L\right)$. 
TABLE 5 European equity options.

\begin{tabular}{|c|c|c|c|c|}
\hline & A & B & $\mathrm{C}$ & $\mathrm{D}$ \\
\hline 1 & Equity Options & & & \\
\hline 2 & & Actual & Theoretical & Sq. errors \\
\hline 3 & Equity $\left(S_{0}\right)$ & 34.27 & 34.27 & 0.00000 \\
\hline 4 & Leverage $(L)$ & 1.90 & 1.90 & 0.00000 \\
\hline 5 & Dividend yield $\left(q_{S}\right)$ & $2.19 \%$ & $2.19 \%$ & 0.00000 \\
\hline 6 & Equity volatility $\left(\sigma_{S}\right)$ & $36.22 \%$ & $36.22 \%$ & 0.00000 \\
\hline 7 & Risk-free rate $(r)$ & $5.50 \%$ & SSE & 0.00000 \\
\hline 8 & Tax rate $(\theta)$ & $35 \%$ & & \\
\hline 9 & Bankruptcy costs rate $(\alpha)$ & $5 \%$ & & \\
\hline 10 & Strike price $(K)$ & 30.00 & & \\
\hline 11 & Time to maturity ( $T$ ) & 1 & & \\
\hline 12 & Asset value $\left(V_{0}\right)$ & 100.00 & & \\
\hline 13 & Payout rate $\left(q_{V}\right)$ & $3.50 \%$ & & \\
\hline 14 & Asset volatility $\left(\sigma_{V}\right)$ & $20.00 \%$ & & \\
\hline 15 & Bond face value $(Z)$ & 50.00 & & \\
\hline 16 & Bankruptcy trigger $\left(V_{b}\right)$ & 31.19 & & \\
\hline 17 & Option to default $(P)$ & 2.72 & & \\
\hline 18 & Option to default volatility $\left(\sigma_{P}\right)$ & $33.17 \%$ & & \\
\hline 19 & Tax claim $\left(G_{0}\right)$ & 35.00 & & \\
\hline 20 & Third parties claim $\left(U_{0}\right)$ & 0.15 & & \\
\hline 21 & Bond $\left(B_{0}\right)$ & 30.58 & & \\
\hline 22 & Critical asset value $\left(V_{T}{ }^{*}\right)$ & 93.09 & & \\
\hline 23 & & call & put & \\
\hline 24 & Down-and-out asset-or-nothing ( $V_{d o c}$ or $V_{d o p}$ ) & 44.67 & 18.10 & \\
\hline 25 & Up-and-out asset-or-nothing ( $P_{\text {uop }}$ or $P_{\text {uor }}$ ) & 0.90 & 0.87 & \\
\hline 26 & Down-and-out cash-or-nothing $\left[(Z+K) R_{d o c}\right.$ or $\left.(Z+K) R_{d o p}\right]$ & 37.86 & 21.30 & \\
\hline 27 & Down-and-in cash-or-nothing ( $K R_{d i}$ ) & 0.00 & 0.00 & \\
\hline 28 & Equity option ( $c$ or $p$ ) & 7.72 & 2.34 & \\
\hline 29 & & $c-p$ & $(1-\theta) S_{d o}-K e^{-r T}$ & \\
\hline 30 & Put-call parity & 5.38 & 5.38 & \\
\hline
\end{tabular}

Here we show how to solve another inverse problem: the model's calibration based on the spreads of credit default swaps and the quotes of equity and equity options. We will consider market daily data on Lehman Brothers and General Motors.

\section{Lehman Brothers}

As in Brigo-Morini-Tarenghi (2009), we focus on three different dates: July $10^{\text {th }} 2007$, June $12^{\text {th }}$ 2008 , September $12^{\text {th }} 2008$. $^{23}$ The last date immediately precedes September $14^{\text {th }} 2008$, when Lehman filed for Chapter 11 bankruptcy protection.

Table 6 reports the (actual and theoretical) CDS spreads of Lehman together with the (actual and theoretical) quotes of Lehman's common stock.

After fixing $\theta, \alpha$, and $r$, we estimated the other model's parameters $\left(V, Z, q_{V}, \sigma_{V}\right)$, by minimizing a loss function defined as the sum of weighted squared $\log$ differences between actual and theoretical values of both CDS spreads and equity quotes. ${ }^{24}$

\footnotetext{
${ }^{23}$ See Brigo, Damiano, Morini, Massimo, and TARenghi, Marco, "Credit Calibration with Structural Models - The Lehman Case and Equity Swaps under Counterparty Risk”, Working Paper, 2009.

${ }^{24}$ The Solver routine in Excel has been used to search for the values of the parameters that minimize the loss function. The routine works well provided that the spreadsheet is structured so that the parameters being searched for have roughly equal values. Since occasionally Solver gives a local minimum, a number of different starting values for the model's parameters has been tested.
} 
TABLE 6 Lehman Brothers: model's calibration based on CDS spreads and equity.

\begin{tabular}{|c|c|c|c|c|c|c|c|c|c|c|c|c|c|c|}
\hline \multirow{2}{*}{ Date } & \multicolumn{10}{|c|}{ CDSs } & \multicolumn{4}{|c|}{ Equity } \\
\hline & & aturity & $\begin{array}{l}\text { Zero } \\
\text { Rate }\end{array}$ & $\begin{array}{l}\text { Default } \\
\text { Prob. }\end{array}$ & $\begin{array}{c}\text { t Survival } \\
\text { Prob. }\end{array}$ & $\begin{array}{l}\text { Default } \\
\text { Intensity }\end{array}$ & $\begin{array}{l}\text { Actual } \\
\text { Spread }\end{array}$ & $\begin{array}{l}\text { l Theoretica } \\
d \text { Spread }\end{array}$ & $\begin{array}{l}\text { al Square } \\
\text { Error }\end{array}$ & & $\begin{array}{c}\text { Mark } \\
\text { Valu }\end{array}$ & $\begin{array}{l}\text { set The } \\
\text { se }\end{array}$ & $\begin{array}{l}\text { heoretical } \\
\text { Value }\end{array}$ & $\begin{array}{l}\text { Squared } \\
\text { Error }\end{array}$ \\
\hline$t$ & & $T-t$ & $r$ & $Q$ & $1-Q$ & $\lambda$ & $s_{m k t}$ & $s$ & {$\left[\ln \left(s_{m k} / s\right.\right.$} & & $S_{m k t}$ & & $S$ & {$\left[\ln \left(S_{m k} / S\right)\right]^{2}$} \\
\hline \multirow[t]{5}{*}{$7 / 10 / 2007$} & & 1 & $5.417 \%$ & $0.68 \%$ & $\begin{array}{l}09.32 \% \\
0\end{array}$ & $0.68 \%$ & 16 & 14 & 2.11 & & 69.67 & & 69.67 & 0.000 \\
\hline & & 3 & $5.322 \%$ & $6.95 \%$ & \% $93.05 \%$ & $2.40 \%$ & 29 & 48 & 25.55 & & & & & \multirow{2}{*}{$\begin{array}{c}\text { Sum of } \\
\text { Sq. Errors } \\
\end{array}$} \\
\hline & & 5 & $5.437 \%$ & $11.58 \%$ & $\% \quad 88.42 \%$ & $2.46 \%$ & 45 & 50 & 1.02 & & & & & \\
\hline & & 7 & $5.540 \%$ & $14.53 \%$ & \% $\quad 85.47 \%$ & $2.24 \%$ & 50 & 46 & 0.55 & & & & & SSE \\
\hline & & 10 & $5.656 \%$ & $17.25 \%$ & \% $82.75 \%$ & $1.89 \%$ & 58 & 41 & 11.85 & & & & & 41.08 \\
\hline \multirow[t]{5}{*}{$6 / 12 / 2008$} & & 1 & $3.490 \%$ & $13.69 \%$ & $86.31 \%$ & $14.72 \%$ & 397 & 380 & 0.18 & & 22.5 & & 22.51 & 0.000 \\
\hline & & 3 & $4.289 \%$ & $32.67 \%$ & $67.33 \%$ & $13.19 \%$ & 315 & 354 & 1.34 & & & & & \multirow{2}{*}{$\begin{array}{c}\begin{array}{c}\text { Sum of } \\
\text { Sq. Errors }\end{array} \\
\end{array}$} \\
\hline & & 5 & $4.608 \%$ & $40.37 \%$ & $59.63 \%$ & $10.34 \%$ & 277 & 294 & 0.34 & & & & & \\
\hline & & 7 & $4.772 \%$ & $44.63 \%$ & $55.37 \%$ & $8.44 \%$ & 258 & 254 & 0.02 & & & & & SSE \\
\hline & & 10 & $4.925 \%$ & $48.40 \%$ & $51.60 \%$ & $6.62 \%$ & 240 & 216 & 1.11 & & & & & 3.01 \\
\hline \multirow[t]{5}{*}{$9 / 12 / 2008$} & & 1 & $3.122 \%$ & $35.83 \%$ & $64.17 \%$ & $44.36 \%$ & 1,437 & 1,393 & 0.10 & & 3.65 & & 3.65 & 0.000 \\
\hline & & 3 & $3.465 \%$ & $55.40 \%$ & $44.60 \%$ & $26.91 \%$ & 902 & 949 & 0.26 & & & & & \multirow{2}{*}{$\begin{array}{c}\begin{array}{c}\text { Sum of } \\
\text { Sq. Errors }\end{array} \\
\end{array}$} \\
\hline & & 5 & $3.853 \%$ & $62.08 \%$ & $37.92 \%$ & $19.39 \%$ & 710 & 752 & 0.32 & & & & & \\
\hline & & 7 & $4.123 \%$ & $65.67 \%$ & $34.33 \%$ & $15.27 \%$ & 636 & 641 & 0.01 & & & & & SSE \\
\hline & & 10 & $4.388 \%$ & $68.85 \%$ & $31.15 \%$ & $11.66 \%$ & 588 & 543 & 0.63 & & & & & 1.31 \\
\hline \multicolumn{6}{|c|}{ Model's Parameters } & \multicolumn{9}{|c|}{ Model's Output } \\
\hline Date & $\begin{array}{l}\text { Asset } \\
\text { Value }\end{array}$ & $\begin{array}{l}t \text { Bon } \\
\text { e Face I }\end{array}$ & $\begin{array}{l}\text { nd's I } \\
\text { Value }\end{array}$ & $\begin{array}{c}\text { Payout } \\
\text { Rate } V\end{array}$ & $\begin{array}{c}\text { Asset } \\
\text { Volatility }\end{array}$ & Lever & rage ${ }^{B}$ & $\begin{array}{l}\text { ankruptcy } \\
\text { Trigger to }\end{array}$ & $\begin{array}{l}\text { Option } \\
\text { o Default }\end{array}$ & $\begin{array}{l}O p \\
\text { Defa }\end{array}$ & $\begin{array}{l}\text { in to } \\
\text { t Vol. }\end{array}$ & Bond & $\begin{array}{l}\text { Bond } \\
\text { Yield }\end{array}$ & $\begin{array}{c}\text { Recovery } \\
\text { Rate }\end{array}$ \\
\hline$t$ & V & & $Z$ & $q_{V}$ & $\sigma_{V}$ & $L$ & 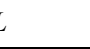 & $V_{b}$ & $P$ & & $\tau_{P}$ & $B_{0}$ & $y$ & $R$ \\
\hline $7 / 10 / 2007$ & 564.5 & & 69.6 & $0,01 \%$ & $14.94 \%$ & 5.26 & 69 & 392.1 & 12.2 & & $63 \%$ & 295.3 & $3 \quad 5.85 \%$ & $79.35 \%$ \\
\hline $6 / 12 / 2008$ & 450.1 & & 64.1 & $0,01 \%$ & $16.99 \%$ & 13.02 & 022 & 358.8 & 48.7 & & $89 \%$ & 264.7 & $7 \quad 5.61 \%$ & $73.47 \%$ \\
\hline $9 / 12 / 2008$ & 168.6 & 200 & 0.5 & $0,01 \%$ & $18.36 \%$ & 30.10 & 164 & 144.8 & 37.5 & & $71 \%$ & 102.8 & $8 \quad 5.56 \%$ & $68.63 \%$ \\
\hline
\end{tabular}

Note: -The model's exogenous parameters are $\theta=35 \%, \alpha=5 \%, r=5.66 \%$ (10 Jul 2007), 4.92\% (12 Jun 2008), 4.39\% (12 Sep 2008). All the weights have been set to 1, except for equity weights, which are 30 (10 Jul 2007), 20 (12 Jun 2008), 10 (12 Sep 2008).

Log differences have been used because CDS spreads and equity quotes are measured in different units (and have different levels). Weights allow for the perfect fit of the equity quotes.

The cross-section estimation of the model parameters has been carried out separately for each of the three above mentioned dates. Results conform to expectations:

1. the assets' value, $V$, diminishes as time passes by;

2. leverage, $L$, increases throughout the observation period (from 5.269 to 30.164). As in (18), $L$ is the ratio between the after-tax value, $(1-\theta) \mathrm{V}$, of firm's assets and the value, $S$, of equity;

3. simultaneously, also the business risk, measured by $\sigma_{V}$, progressively increases (from $14.94 \%$ to $18.36 \%$ );

4. the term structures of (unconditional, risk neutral) default probabilities and (conditional, risk neutral) default intensities shift upward. However, on September $12^{\text {th }} 2008$ the immediate future of Lehman Brothers was not at all clear: the 1-year default and survival probabilities were $35.83 \%$ and $64.17 \%$, respectively; ${ }^{25}$

5 . the recovery rate, $R$, slightly goes down (from $79.35 \%$ to $68.63 \%$ ).

\footnotetext{
${ }^{25}$ The implied default intensities differ from those calculated in Brigo et al., op. cit., because our values are based on different recovery rates.
} 


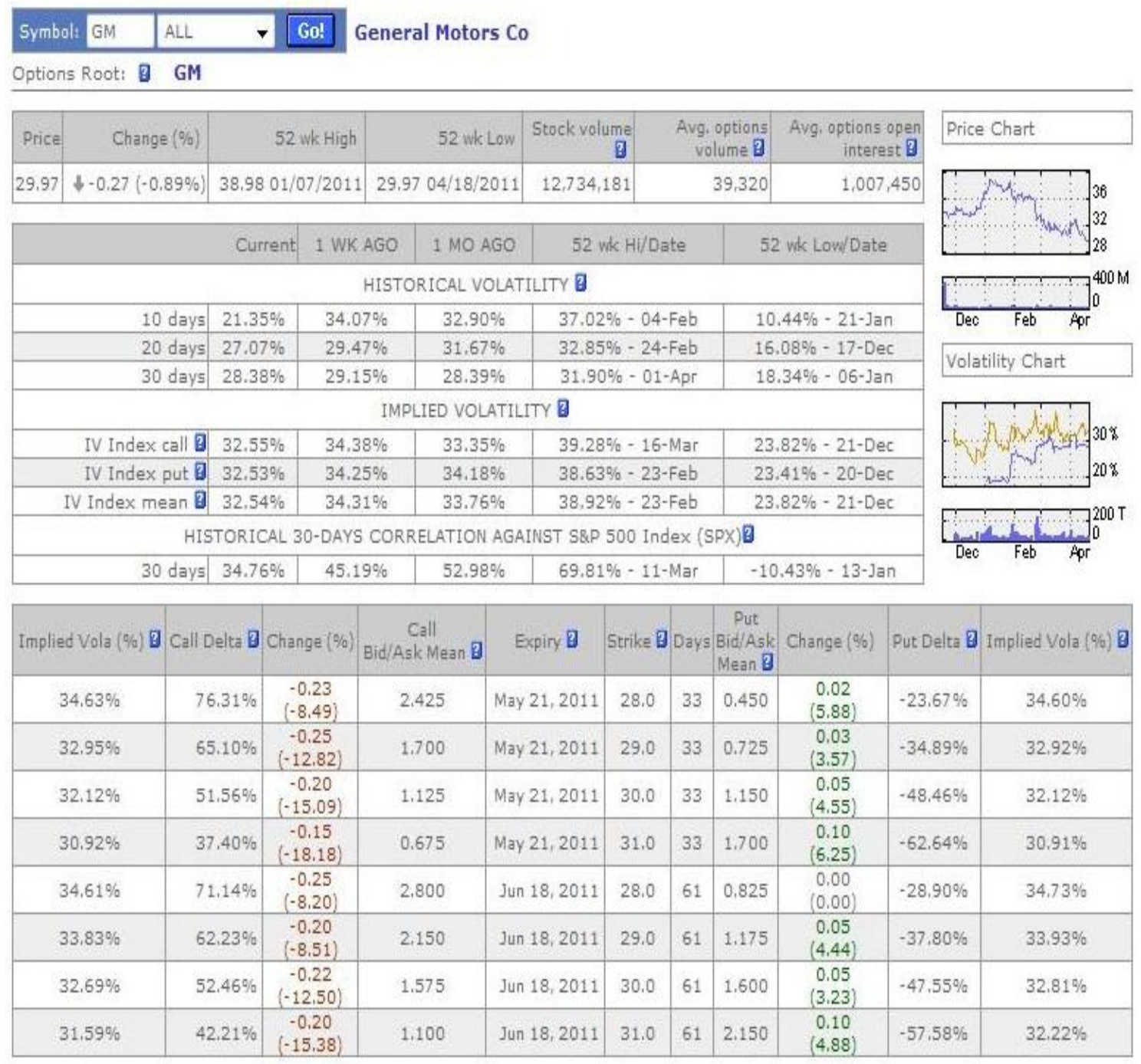

Figure 4 CBOE options quotes of General Motors: implied volatilities (April 18 $\left.{ }^{\text {th }}, 2011\right)$. Source: IVolatility.com

\section{General Motors}

As a second application of the model, we used market data on General Motors (GM). On April $18^{\text {th }}$ 2011, the latest available date, we observed CDS spreads, options quotes, equity and equity volatility.

The implied volatilities of CBOE options quotes of GM exhibit the usual downward-sloping relationship with respect to strike prices (Figure 4).

The calibration's results are shown in Table 7. The model fits less well than for Lehman. The valuations made in the market for CDSs do not seem to be aligned with the market quotes of equity and equity options. ${ }^{26}$ In order to explain the high CDS spreads, it would be necessary to assume a very high business risk, which would determine unreasonably high levels of equity volatility.

The conclusion, based on the model, is that the market for CDSs seems to have been much more pessimistic on the future of GM than the market for equity and equity options. If one trusts the model, there should have been room for convergence trading.

\footnotetext{
${ }^{26}$ Some new empirical evidence documents a "slow information diffusion between the CDS market and the stock market". See HAN, Bing, and ZHOU, Yi, "Term Structure of Credit Default Swap Spreads and Cross-Section of Stock Returns", Working Paper, March 2011.
} 
TABLE 7 General Motors: model's calibration based on CDS spreads, equity options, equity, and equity volatility.

\begin{tabular}{cccccccccc}
\hline \multicolumn{10}{c}{ CDSs } \\
\hline $\begin{array}{c}\text { Current } \\
\text { Date }\end{array}$ & Maturity & $\begin{array}{c}\text { Zero } \\
\text { Rate }\end{array}$ & $\begin{array}{c}\text { Default } \\
\text { Probability }\end{array}$ & $\begin{array}{c}\text { Survival } \\
\text { Probability }\end{array}$ & $\begin{array}{c}\text { Av. Default } \\
\text { Intensity }\end{array}$ & $\begin{array}{c}\text { Actual } \\
\text { Spread }\end{array}$ & $\begin{array}{c}\text { Theoretical } \\
\text { Spread }\end{array}$ & $\begin{array}{c}\text { Squared } \\
\text { Error }\end{array}$ \\
\hline$t$ & $T-t$ & $r$ & $Q$ & $1-Q$ & $\lambda$ & $s_{m k t}$ & $s$ & {$\left[\ln \left(s_{m k} / s\right)\right]^{2}$} \\
\hline $4 / 18 / 2011$ & 1 & $0.772 \%$ & $1.51 \%$ & $98.49 \%$ & $1.52 \%$ & 94 & 68 & $10.23 \%$ \\
& 3 & $1.353 \%$ & $19.37 \%$ & $80.63 \%$ & $7.18 \%$ & 214 & 304 & $12.34 \%$ \\
& 5 & $2.284 \%$ & $34.58 \%$ & $65.42 \%$ & $8.49 \%$ & 331 & 355 & $0.50 \%$ \\
& 7 & $2.953 \%$ & $45.27 \%$ & $54.73 \%$ & $8.61 \%$ & 377 & 364 & $0.12 \%$ \\
& 10 & $3.568 \%$ & $56.24 \%$ & $43.76 \%$ & $8.26 \%$ & 408 & 361 & $1.50 \%$ \\
\hline & & & & & & & & $24.68 \%$
\end{tabular}

Equity Options

\begin{tabular}{cccccccccc}
\hline Maturity & $\begin{array}{c}\text { Time } \\
\text { to Maturity }\end{array}$ & $\begin{array}{c}\text { Zero } \\
\text { Rate }\end{array}$ & Strike & $\begin{array}{c}\text { Implied } \\
\text { Volatility }\end{array}$ & $\begin{array}{c}\text { Critical } \\
\text { Value }\end{array}$ & $\begin{array}{c}\text { Market } \\
\text { Value }\end{array}$ & $\begin{array}{c}\text { Theoretical } \\
\text { Value }\end{array}$ & $\begin{array}{c}\text { Squared } \\
\text { Error }\end{array}$ \\
\hline$T$ & $T-t$ & $r$ & $K$ & $\sigma_{\text {imp }}$ & $V_{T}{ }^{*}$ & $c_{m k t}$ & $c$ & {$\left[\ln \left(c_{m k} / c\right)\right]^{2}$} \\
\hline $5 / 21 / 2011$ & 0.09 & $0.212 \%$ & 28 & $34.63 \%$ & 468.2 & 2.425 & 1.682 & $13.40 \%$ \\
& & $0.212 \%$ & 29 & $32.95 \%$ & 471.0 & 1.700 & 1.347 & $5.42 \%$ \\
& & $0.212 \%$ & 30 & $32.12 \%$ & 473.8 & 1.125 & 1.066 & $0.29 \%$ \\
& & $0.212 \%$ & 31 & $30.92 \%$ & 476.5 & 0.675 & 0.834 & $4.49 \%$ \\
\hline $6 / 18 / 2011$ & 0.17 & & & & & & & & $23.60 \%$ \\
& & & & & & & & & \\
& & $0.247 \%$ & 28 & $34.61 \%$ & 468.2 & 2.800 & 2.572 & $0.72 \%$ \\
& & $0.247 \%$ & 29 & $33.83 \%$ & 471.0 & 2.150 & 2.205 & $0.06 \%$ \\
& & & 30 & $32.69 \%$ & 473.8 & 1.575 & 1.881 & $3.15 \%$ \\
& $0.247 \%$ & 31 & $31.59 \%$ & 476.5 & 1.100 & 1.595 & $13.81 \%$ \\
\hline
\end{tabular}

\begin{tabular}{cccc}
\multicolumn{4}{c}{ Equity } \\
\hline $\begin{array}{c}\text { Current } \\
\text { Date }\end{array}$ & $\begin{array}{c}\text { Market } \\
\text { Value }\end{array}$ & $\begin{array}{c}\text { Theoretical } \\
\text { Value }\end{array}$ & $\begin{array}{c}\text { Squared } \\
\text { Error }\end{array}$ \\
\hline$t$ & $S_{m k t}$ & $S$ & {$\left[\ln \left(S_{m k t} / S\right)\right]^{2}$} \\
\hline $4 / 18 / 2011$ & 29.97 & 26.08 & $1.93 \%$ \\
\hline
\end{tabular}

\begin{tabular}{ccc}
\multicolumn{3}{c}{ Equity Volatility } \\
\hline $\begin{array}{c}\text { Market } \\
\text { Value }\end{array}$ & $\begin{array}{c}\text { Theoretical } \\
\text { Value }\end{array}$ & $\begin{array}{c}\text { Squared } \\
\text { Error }\end{array}$ \\
\hline$\sigma_{m k t}$ & $\sigma_{S}$ & {$\left[\ln \left(\sigma_{m k t} / \sigma_{S}\right)\right]^{2}$} \\
\hline $32.54 \%$ & $78.24 \%$ & $76.96 \%$ \\
\hline
\end{tabular}

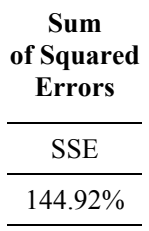

\begin{tabular}{cccc}
\multicolumn{4}{c}{ Model's Parameters } \\
\hline $\begin{array}{c}\text { Asset } \\
\text { Value }\end{array}$ & $\begin{array}{c}\text { Bond's } \\
\text { Face Value }\end{array}$ & $\begin{array}{c}\text { Payout } \\
\text { Rate }\end{array}$ & $\begin{array}{c}\text { Asset } \\
\text { Volatility }\end{array}$ \\
\hline$V$ & $Z$ & $q_{V}$ & $\sigma_{V}$ \\
\hline 462.6 & 588.7 & $4.39 \%$ & $12.82 \%$
\end{tabular}

\begin{tabular}{ccccccc}
\multicolumn{8}{c}{ Model's Output } \\
\hline Leverage & $\begin{array}{c}\text { Bankruptcy } \\
\text { Trigger }\end{array}$ & $\begin{array}{c}\text { Option } \\
\text { to Default }\end{array}$ & $\begin{array}{c}\text { Option to } \\
\text { Default Vol. }\end{array}$ & Bond & $\begin{array}{c}\text { Bond } \\
\text { Yield }\end{array}$ & $\begin{array}{c}\text { Recovery } \\
\text { Rate }\end{array}$ \\
\hline$L$ & $V_{b}$ & $P$ & $\sigma_{P}$ & $B_{0}$ & $y$ & $R$ \\
\hline 11.5 & 333.9 & 166.2 & $16.80 \%$ & 267.6 & $5.10 \%$ & $53.89 \%$
\end{tabular}

Note: The model's exogenous parameters are $\theta=35 \%, \alpha=5 \%, r=3.57 \%$. All the weights have been set to 1 .

\section{CONCLUSIONS}

We have presented a structural model à la Leland (1994), which can be used to value credit and equity derivatives in a unified framework. In the model, stockholders issue a perpetual fixed-rate bond and hold a perpetual American option to default written on the firm's assets. Stockholders determine the (constant) optimal default point which maximizes the value of equity. As a consequence, the $T$ year default probabilities are equal to the probabilities that the asset value reaches the default point by time $T$. Default probabilities can be calculated by using the first-passage time distribution func- 
tion. Similarly, the $T$-year CDS spreads can be calculated by using the value of finite-maturity firsttouch digital options.

Equity is equal to a portfolio which is long on the firm's assets, short on a perpetual risk-free bond, long on a perpetual American option to default and short on a tax claim. Equity volatility is stochastic, being a complex function of both value and volatility of firm's assets. By simply adding an extra parameter, leverage, to the standard input list of the Black-Scholes-Merton formulas, traders can evaluate equity options in a way which is consistent with the downward-sloping volatility skew observed in equity options markets. Given the "option-like" nature of equity, equity options are compound options written on the firm's assets. They can be valuated by the Rubinstein-Reiner (1991) formulas for binary barrier options, which only require the calculation of the univariate normal distribution function.

The model can be used to solve direct and inverse problems. As an example of a direct problem, we have determined the value of equity options based on two different input lists and, as an example of an inverse problem, we showed the calculation of implied default probabilities based on actual default probabilities reported by Moody's for some rating classes. Finally, we have considered market data on Lehman Brothers and General Motors and show how to calibrate the model by using the CDS spreads and the quotes of equity and equity options. 


\section{REFERENCES}

BAI, Jennie, and Wu, Liuren, “Anchoring Corporate Credit Spreads to Firm Fundamentals”, Working Paper, June 2010.

BARone, Gaia, "European Compound Options Written on Perpetual American Options", Journal of Derivatives, Spring 2013.

Barone, Gaia, "Equity Options and Bond Options in the Leland Model", "Tor Vergata" University of Rome, Working Paper, March 2011. Downloadable at http://ssrn.com/author=1004723.

Black, Fischer S., and Cox, John C., "Valuing Corporate Securities - Some Effects of Bond Indenture Provisions", Journal of Finance 31 (2), 351-367, 1976.

Brigo, Damiano, Morini, Massimo, and TARENGHi, Marco, "Credit Calibration with Structural Models - The Lehman Case and Equity Swaps under Counterparty Risk", Working Paper, 2009.

Cox, John C., Ingersoll, Jonathan E., and Ross, Stephen A., "Duration and the Measurement of Basis Risk", Journal of Business, vol. 52, no. 1, pp. 51-61, January 1979.

Cox, John C., Ingersoll, Jonathan E., and Ross, Stephen A., “An Analysis of Variable Rate Loan Contracts”, Journal of Finance, vol. 35, no. 2, pp. 389-403, May 1980.

DÉCAMPS, Jean-Paul, and Villeneuve, Stéphane, "On the modeling of Debt Maturity and Endogenous Default - A Caveat", Working Paper, May 2008.

Duffie, Darrell, and Singleton, Ken J., Credit Risk, Princeton University Press, 2003.

ERICSSON, Jan, and ReNEBY, Joel, “A Note on Contingent Claims Pricing with Non-Traded Assets”, SSE/EFI Working Paper Series in Economics and Finance No. 314, June 2002.

Goldstein, Robert, Ju, Nengjiu, and Leland, Hayne, “An EBIT-Based Model of Dynamic Capital Structure”, Journal of Business, vol. 74, no. 4, 2001.

HaN, Bing, and Zhou, Yi, "Term Structure of Credit Default Swap Spreads and Cross-Section of Stock Returns", Working Paper, March 2011.

Hull, John C., Options, Futures, and Other Derivatives, Pearson, $8^{\text {th }}$ ed., 2011.

Ingersoll, Jonathan E., Theory of Financial Decision Making, Rowman \& Littlefield, 1987.

Kahn, Joseph, and Truell, Peter, “Troubled Investment Fund's Bets Now Estimated at \$1.25 Trillion”, Wall Street Journal, September 26, 1998.

Leland, Hayne, "Corporate Debt Value, Bond Covenants, and Optimal Capital Structure", Journal of Finance, 49 (4), pp. 1213-52, September 1994.

Leland, Hayne, "Bond Prices, Yield Spreads, and Optimal Capital Structure with Default Risk", Finance Working Paper no. 240, Haas School of Business, University of California at Berkeley, January 1995.

Leland, Hayne, "Princeton Lectures" [Lecture 1 - Pros and Cons of Structural Models - An Introduction, Lecture 2 A New Structural Model, Lecture 3 - Financial Synergies and the Optimal Scope of the Firm - Implications for Mergers and Structured Finance], 2006.

LELAND, Hayne, "Structural Models and the Credit Crisis", China International Conference in Finance, July 8, 2009.

Merton, Robert C., "On the Pricing of Corporate Debt: The Risk Structure of Interest Rates," Journal of Finance 29, No. 2 (May 1974), pp. 449-470, reprinted in Robert C. Merton, Continuous-Time Finance, Chapter 12 (Malden, MA: Blackwell, 1990), pp. 388-412.

Modigliani, Franco, and Miller, Merton H., "The cost of capital, corporation finance and the theory of investment", American Economic Review, vol. 48, no. 3, pp. 267-297, June 1958.

Rubinstein, Mark e ReInER, Eric, “Unscrambling the Binary Code”, Risk, vol. 4, no. 9, pp. 75-83, October 1991.

Toft, Klaus Bjerre Toft, "Options on Leveraged Equity with Default Risk”, Walter A. Haas School of Business, University of California at Berkeley, July 1994.

TofT, Klaus Bjerre Toft, and PrUCYK, Bryan, “Options on Leveraged Equity: Theory and Empirical Tests”, Journal of Finance, Vol. 52, No. 3, pp. 1151-1180, July 1997.

WARnER, Jerold B., "Bankruptcy Costs: Some Evidence”, Journal of Finance, vol. 32, no. 2, pp. 337-47, May 1977. 